\section{OAK RIDGE NATIONAL LABORATORY}

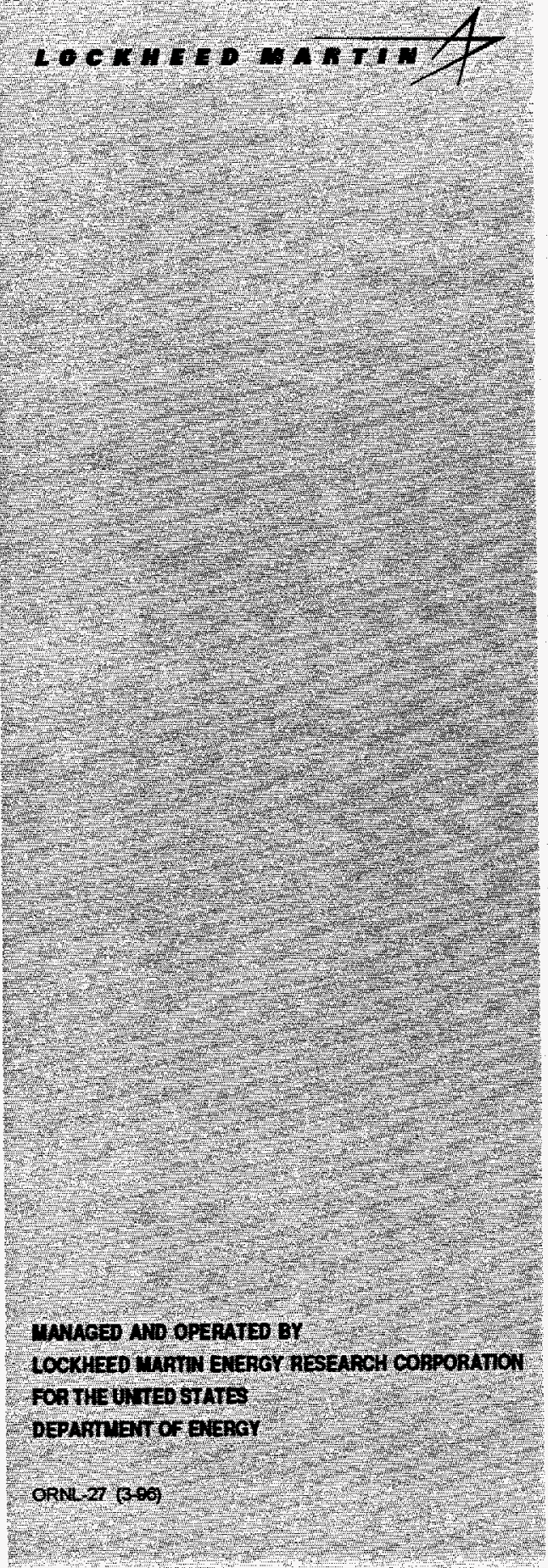

SEP 09020

OSTI

Effective Porosity and Pore-Throat Sizes of Mudrock Saprolite from the Nolichucky Shale Within Bear Creek Valley on the Oak Ridge Reservation: Implications for Contaminant Transport and Retardation Through Matrix Diffusion

J. Dorsch

T. J. Katsube

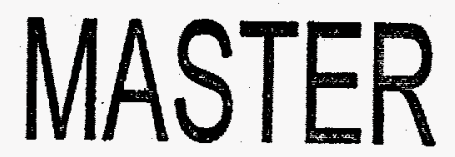


This report has been reproduced directly from the best available copy.

Available to DOE and DOE contractors from the Office of Scientific and Technical

Information, P.O.Box 62, Oak Ridge, TN 37831; prices available from (423) 576-8401, FTS 626-8401.

Available to the public from the National Technical Information Service, U.S. Department

of Commerce, 5285 Port Royal Rd., Springfield, VA 22161

This report was prepared a an account of work sponsored by an agency of the United States Government. Neither the United States Government nor any agency thereof, nor any of their employees, makes any warranty, express or implied, or assumes any legal liability or responsibility for the accuracy. completeness, or usefulness of any intormation, apparatus, product, or process disclosed, or represents that its use would not infringe privately owned rights. Reference herein to any specific commercial product. process, or service by trade name, trademark, manufacturer, or otherwise, does not necessarily constitute or imply its endorsement, recommendation, or favoring by the United States Government or any agency thereof. The view and opinions of authors expressed herein do not necessarily state or reflect those of the UnitedStatesGovernment or any agency thereot. 


\title{
EFFECTIVE POROSITY AND PORE-THROAT SIZES OF MUDROCK SAPROLITE FROM THE NOLICHUCKY SHALE WITHIN BEAR CREEK VALLEY ON THE OAK RIDGE RESERVATION: IMPLICATIONS FOR CONTAMINANT TRANSPORT AND RETARDATION THROUGH MATRIX DIFFUSION
}

\author{
J. Dorsch ${ }^{1}$ \\ T. J. Katsube ${ }^{2}$ \\ ${ }^{1}$ Environmental Sciences Division, Oak Ridge National Laboratory, Oak Ridge, TN 37831-6400 \\ 2 Geological Survey of Canada, Mineral Resources Division, Ottawa, Ontario K1A 0E8
}

Date Issued--May, 1996

\author{
Prepared by the \\ Environmental Sciences Division \\ Oak Ridge National Laboratory \\ Prepared for \\ Groundwater Program Office \\ under budget and reporting code EU 2010301 \\ OAK RIDGE NATIONAL LABORATORY \\ Oak Ridge, Tennessee 37831-6285 \\ managed by \\ LOCKHEED MARTIN ENERGY RESEARCH, CORP. \\ for the \\ US DEPARTMENT OF ENERGY \\ under contract DE-AC05-96OR22464
}




\section{Table of Contents}

Page

Figures V

Tables vii

Acknowledgments vii

Executive Summary viii

Purpose .1

Introduction

Conasauga Group Saprolite on the Oak Ridge Reservation ......................2

Matrix Diffusion and Effective Porosity $\quad$..............................................6

Petrophysical Measurement Techniques $\quad$.......................................................9

Mercury Porosimetry ..........................................................................10

Principle $\quad$..........................................................................10

Washburn Equation ...............................................................10

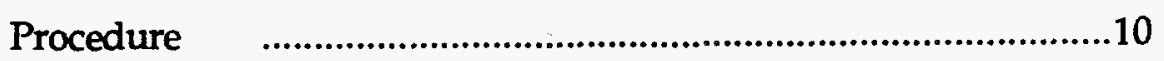

Effective Porosity $\quad$......................................................................13

Geometric Mean of Pore-Throat Sizes

Helium Porosimetry ................................................................................14

Principle $\quad$.....................................................................14

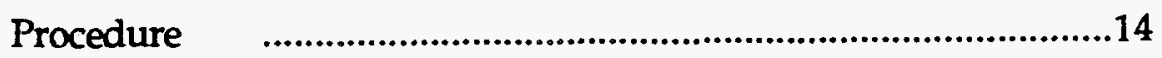

Effective Porosity $\quad$......................................................................14

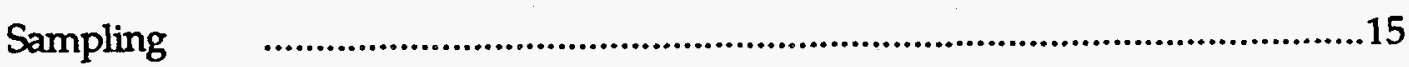

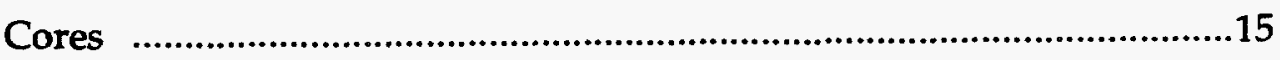

Sampling Intervals $\quad$......................................................................15

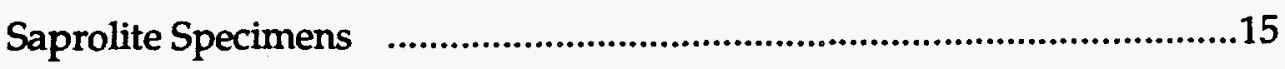

Mudrock-Fragment Specimens $\quad$............................................18 


\section{DISCLAIMER}

Portions of this document may be illegible in electronic image products. Images are produced from the best available original document. 


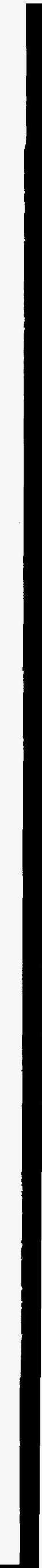


Grain-Density and Bulk-Density Data .20

Specimen Bulk-Density

Specimen Grain-Density

Pore-Throat-Size Data

Saprolite Mudrock-Fragments

Saprolite Groundmass

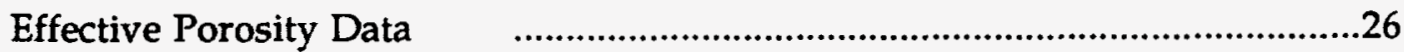

Helium Porosimetry .................................................................26

Mercury Porosimetry ...................................................................28

Calculated Interval Effective Porosity $\quad$.........................................29

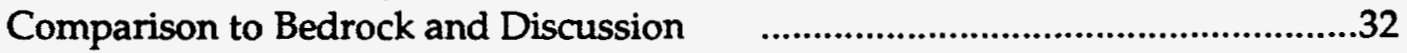

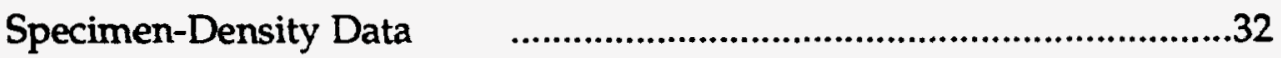

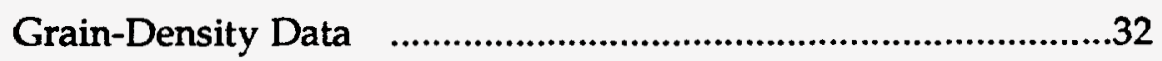

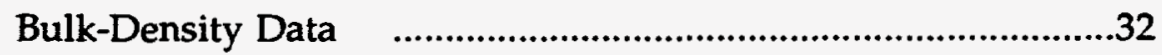

Density Data with Depth $\quad$........................................................34

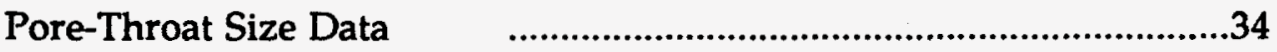

Effective Porosity Data $\quad$................................................................41

Comparison of Effective Porosities .........................................41

Comparison to Bedrock $\quad$.........................................................43

Effective Porosities with Depth $\quad$.........................................45

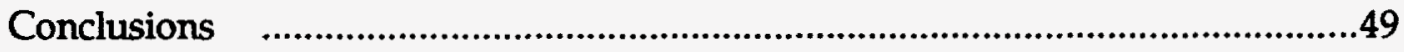

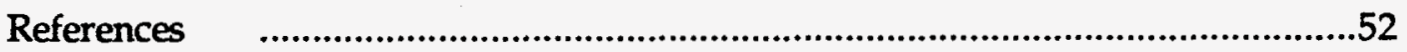

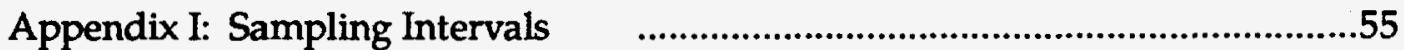

Appendix II: Statistical Measures …..........................................................56

Appendix III: Results - Pore-Throat Sizes ..............................................58

Appendix IV: Pore-Throat-Size Distribution Curves $\quad$..............................60 
Appendix V: Data for Calculation of Interval Effective Porosity

Appendix VI: Petrophysical Data of Nolichucky Shale Bedrock

(Bear Creek Valley) .66 


\section{FIGURES}

Figure

Page

1 Schematic vertical relationship of flow zones within aquitards on the ORR

2 Soil-saprolite-bedrock weathering column .5

3 Block diagrams illustrating the diffusion of contaminant species from a fracture into the surrounding saprolite "matrix" .7

4 Capillary-pressure curves plotting the measured injection pressure and/or the calculated pore-throat diameter versus amount/volume of intruded mercury

5 Illustration of the importance of pore throats for controlling access to pores

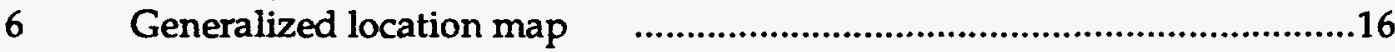

$7 \quad$ Stratigraphic cross section oriented perpendicular to regional dip $\quad . . . . . . .17$

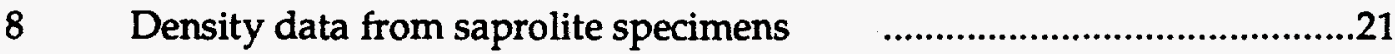

9 Typical pore-throat-size distribution curves for saprolite developed from mudrock of the Nolichucky Shale .24

10 Effective porosity data from saprolite specimens

11 Calculated effective porosity values for selected saprolite intervals

12 Comparison of bulk and grain densities from saprolite specimens and Nolichucky Shale specimens

13 Specimen density-pairs for Nolichucky Shale and saprolite specimens

14 Superimposed pore-throat-size distribution curves of typical saprolite and Nolichucky Shale specimens .36

15 Simplified illustration of the inferred boundaries of weathering 
zones within a saprolite mantle

16 Pore-throat-size distribution curves of saprolite groundmass specimens with superimposed sizes of colloidal tracers

17 Diagram plotting effective porosity based on mercury porosimetry against effective porosity based on helium porosimetry

18 Comparison of helium-porosimetry and mercury-porosimetry effective porosity data from Nolichucky Shale and saprolite

19 Effective porosity with depth for Nolichucky Shale and saprolite specimens .46

20 Calculated interval effective porosities for saprolite matrix against depth .48 


\section{TABLES}

Table

Page

1 Data on specimen grain-density $\delta_{\mathrm{He}}$ and specimen

bulk-density $\delta_{\mathrm{Hg}}$ for mudrock-saprolite specimens

2 Data on effective porosity of saprolite specimens

.26

3 Summary of petrophysical information on saprolite specimens

from Bear Creek Valley on the ORR .50

\section{ACKNOWLEDGMENTS}

Gerilynn R. Moline and William E. Sanford are thanked for critically reading a previous draft of this report which resulted in significant improvements. Mark P. Elles is acknowledged for his time discussing aspect of soil and saprolite characteristics in the core barn. Any shortcomings, however, remain the responsibility of the authors. The support from the Y-12 HSE\&A-Division, administered through Judy A. Hodgins is most gratefully acknowledged. The research was supported in part by an appointment to the Oak Ridge National Laboratory Postdoctoral Research Associates Program (awarded to J. Dorsch) administered jointly by the Oak Ridge National Laboratory and the Oak Ridge Institute for Science and Education. 


\section{EXECUTIVE SUMMARY}

Matrix diffusion is regarded as an important transport mechanism within the low-permeability dual-porosity saprolite mantle on the Oak Ridge Reservation (ORR). In order to evaluate and model matrix diffusion, a knowledge of the effective porosity of the saprolite matrix is necessary. To that end, mudrock-saprolite specimens from Bear Creek Valley on the ORR, developed from the Nolichucky Shale through weathering, were analyzed with helium and mercury porosimetry. The saprolite matrix of the fresh core samples is composed of the volumetrically more abundant saprolite groundmass which contains varying fractions of less weathered mudrock-fragments. Average effective porosities determined by helium porosimetry, judged to provide the best estimate for true (maximum) effective porosity, are $16.1 \%$ for mudrock fragments and $39.0 \%$ for groundmass. Average effective porosities from mercury porosimetry are $11.9 \%$ for mudrock fragments and $33.7 \%(\mathrm{Hg} 2)$ or $26.8 \%(\mathrm{Hg} 1)$ for groundmass. The progressive effect of weathering is apparent through an increase in effective porosity combined with a decrease in bulk-density, when specimens of bedrock mudrock, saprolite mudrock-fragments, and saprolite groundmass are compared. Weathering most likely involved the loss of cement and of some grain material, and the mechanical loosening of the grain fabric. Pore-throat-size distribution curves for saprolite mudrockfragments (skewed right, modes 5 to $20 \mathrm{~nm}$, majority of pore throats $<100 \mathrm{~nm}$ ) are distinctly different from distribution curves of saprolite groundmass (skewed left, modes 1200 to $5000 \mathrm{~nm}$, majority of pore throats $>100 \mathrm{~nm}$ ). Together with the overall shift of the throat-size spectrum toward larger sizes for specimens of bedrock mudrock, saprolite mudrock-fragments, and saprolite groundmass, this again reflects the increasing effect of weathering. The distribution curves also point out that the boundaries of weathering zones are most likely irregular and not parallel to the ground surface. Calculated interval effective porosities characterize larger volumes of saprolite matrix and integrate both mudrock-fragment and groundmass effective porosities. The values range from $51.3 \%$ to $26.2 \%$ and display a smooth decrease with depth, mirroring the saprolite weathering profile. The calculated interval effective porosities are probably best suited for the task of modeling and evaluating matrix diffusion as a transport mechanism within the saprolite mantle. 


\section{PURPOSE}

The purpose of the research reported in this document was the derivation of quantitative data on effective porosity and pore-throat sizes of mudrock saprolite based on state-of-the art petrophysical measurement techniques. The target was the saprolite developed from the Nolichucky Shale of the Conasauga Group within Bear Creek Valley on the Oak Ridge Reservation (ORR). The data are important for the evaluation of matrix diffusion as a transport process within fractured low-permeability geological material such as mudrock saprolite on the ORR. 


\section{INTRODUCTION}

Specimens of saprolite developed from mudrock of the Nolichucky Shale (Upper Cambrian, Conasauga Group) from the Whiteoak Mountain thrust sheet on the Oak Ridge Reservation (ORR) were analyzed. Petrophysical techniques include helium porosimetry and mercury porosimetry. Petrophysical data obtained from the laboratory experiments include effective porosity, pore-throat sizes and their distribution, specimen bulk-density, and specimen grain-density. It is expected that the data from this study will significantly contribute to constraining the modeling of the hydrologic behavior of saprolite developed from mudrock of the Conasauga Group in general and from the Nolichucky Shale specifically.

\section{Conasauga Group Saprolite on the Oak Ridge Reservation}

Saprolite is commonly defined (following Fairbridge, 1968, p. 933) as chemically altered, but coherent and not texturally disintegrated rock rotten in situ. Weathering has removed certain chemical components, but the grain relations remain undisturbed.

Saprolite occupies the zone below the soil horizons and above the bedrock proper. Lietzke (1992) emphasized especially the leaching of calcium carbonate from Conasauga Group lithologies on the ORR.

The thickness of saprolite on the ORR is highly variable (Lietzke, 1992), but common thicknesses of saprolite developed from the Conasauga Group of up to $10 \mathrm{~m}$ are reported (Solomon et al., 1992; Lee et al., 1992). Saprolite retains the structural style obtained by the different clastic lithologies on the ORR (Dreier et al., 1987) predominantly during the Late Paleozoic Alleghanian orogeny. The structural inventory includes different fold generations, faults, and especially a pervasive fracture system. The system is characterized by distinct fracture sets of differing orientation, and was formed during a time span ranging from the Cambrian to the Recent (Lemiszki and Hatcher, 1992).

Four broad hydrologic zones can be identified on the ORR: the near-surface stormflow zone, the vadose zone, the groundwater zone, and the aquiclude (Figure 1; Solomon et al., 1992). Within this hydrologic zonation, mudrock saprolite can be found from the lower part of the stormflow zone, through the vadose zone, down to the watertable interval of the groundwater zone. The degree of weathering generally decreases when moving downward in this section, with a broad transition interval into bedrock. Water saturation occurs within the water-table interval (and below) and (partly to 


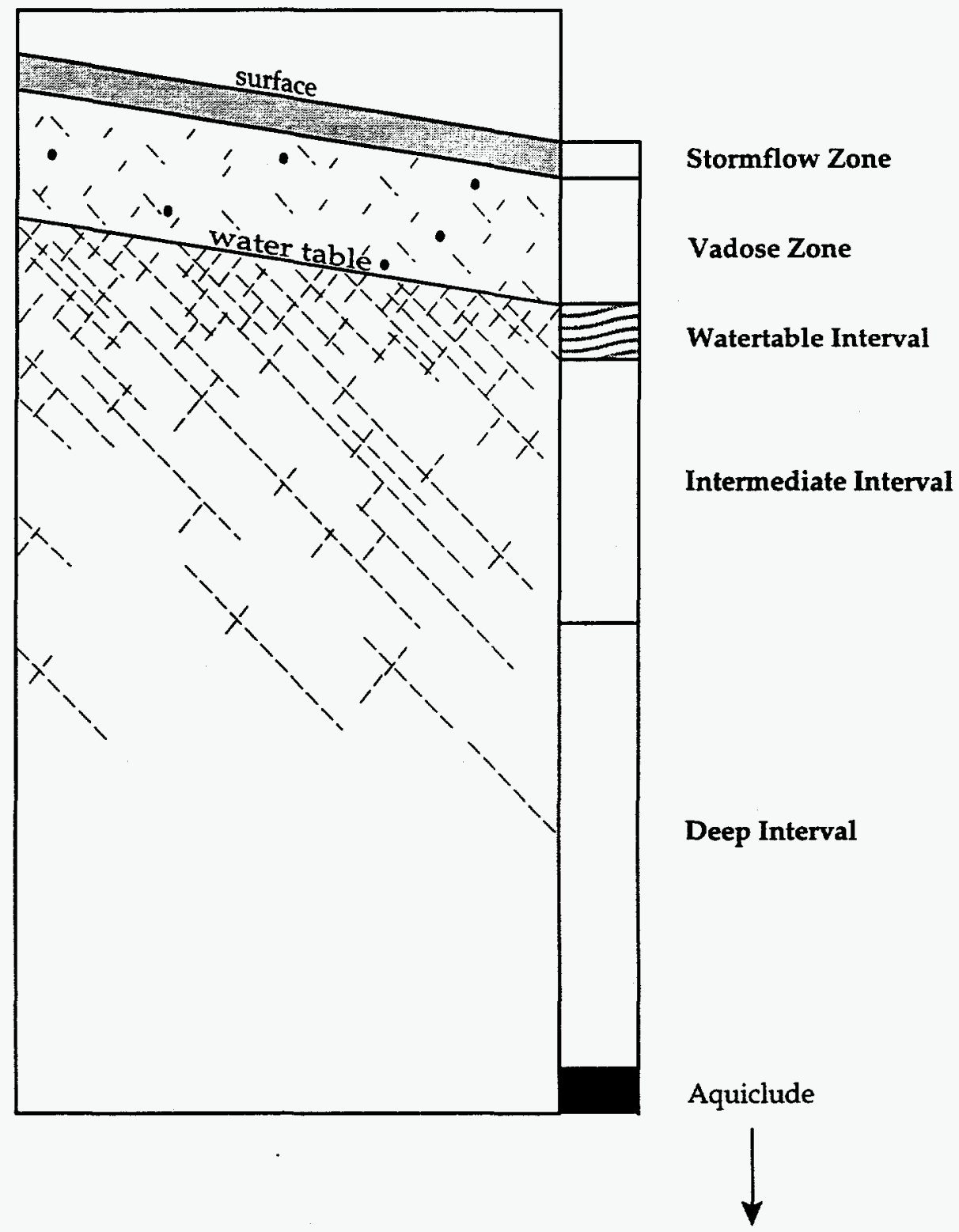

Fig. 1: Schematic vertical relationship of flow zones within aquitards on the ORR (modified after Solomon et al., 1992). 
completely) within the stormflow zone during rain events. Seasonal fluctuations are important in extending the water-table interval into what commonly is the vadose zone. The transition zone from regolith (including saprolite) to bedrock typically can be placed at the base of the water-table interval (Solomon et al., 1992).

The Conasauga Group on the ORR is composed predominantly of mudrock, interbedded with limestone beds (Hasson and Haase, 1988, Dreier et al., 1992). The saprolite developed from the Conasauga Group is most important for environmental concerns on the ORR because the Conasauga Group forms an important aquitard unit (Solomon et al., 1992), and a majority of the waste-disposal activities on the ORR are situated within the saprolite interval above Conasauga bedrock. Excavations routinely intersect the water-table interval. Leakage of material from waste-disposal sites has the potential to contaminate the saprolite, which might be further aggravated by transport of contaminant species through the interconnected fracture system.

Saprolite developed from Conasauga Group mudrock is not expected to be uniform in petrophysical characteristics. The petrophysical characteristics are determined by: 1) the original lithologic variance of the deposits, 2) the diagenetic overprint of the deposits and, most importantly, 3) the difference in weathering. Typical soil-saprolite-bedrock weathering profiles (Figure 2) display a change in the severity of weathering with depth which is expected to be reflected by a commensurate change in petrophysical characteristics from the boundary of the soil B-horizon/Chorizon, through the leached $(\mathrm{Cr} 1)$ and unleached $(\mathrm{Cr} 2)$ saprolite zones, to the contact with bedrock (Figure 2). A drastic change in petrophysical characteristics from the weathering profile to the unweathered bedrock is also expected (Lietzke et al., 1988). This is a qualitative statement because quantitative data on saprolite petrophysical characteristics are not available at the present. Extensive quantitative petrophysical data, however, are available for mudrock of the Conasauga Group below the saprolite zone (Dorsch et al., 1996). This will provide the opportunity to compare the petrophysical characteristics of bedrock with those of saprolite developed from Conasauga Group mudrock. A general summary of the sedimentology and stratigraphy of the Conasauga Group mudrock (bedrock) is provided by Dorsch et al. (1996). 


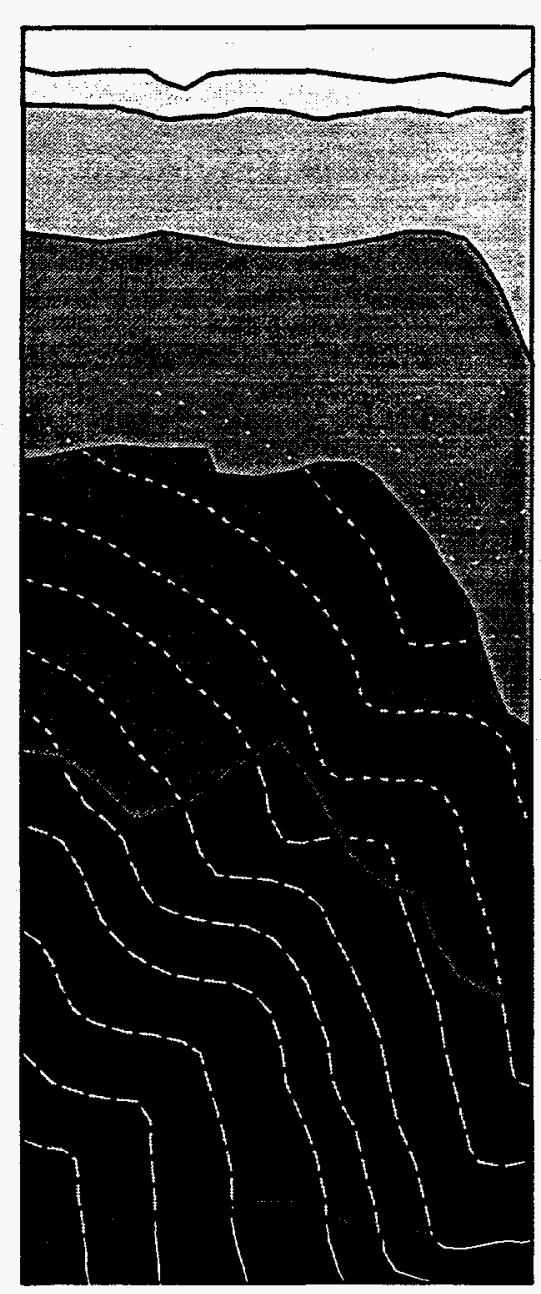

A horizon: zone of leaching and accumulation of carbon

E horizon: zone of intense leaching and loss of clays and oxides

B horizon: zone of accumulation of clays and oxides

C horizon: zone of lower biologic activity

Cr horizon: paralithic material that preclude roots

Cr1: oxidized and leached saprolite

Cr2: oxidized and unleached saprolite

R: lithic material, unoxidized and unleached bedrock

Fig. 2: Soil-saprolite-bedrock weathering column (modified from Lietzke et al., 1988). 
Matrix Diffusion and Effective Porosity

Effective porosity is defined as the ratio of volume of interconnected pore space to total volume of a rock sample. Effective porosity is believed to be an important parameter that controls the extent and effectiveness of diffusive processes within finegrained siliciclastic rocks (e. g., Germain and Frind, 1989; Toran et al., 1995). The importance of matrix diffusion as an agent for efficient material transport in the fractured low-permeability sedimentary rocks and saprolite on the Oak Ridge Reservation was pointed out by Wickliff et al. (1991), Solomon et al. (1992), Shevenell et al. (1994), and Sanford et al. (1994).

Figure 3 illustrates the potential importance of matrix diffusion for contaminant transport within fractured low-permeability mudrock saprolite. Contaminated water actively moves through the interconnected fracture network, but through the process of diffusion contaminants are able to access the interconnected pore space of the surrounding matrix blocks. Access to the pore water of the saprolite matrix is through matrix pores connected to the fracture network. The result of this mass transfer by diffusion will be an apparent retardation of the spread of the contaminant species carried by water within the interconnected fracture network (e. g., Neretnieks, 1980, Tang et al., 1981; McKay et al., 1993). This scenario will develop while the primary contaminant source is present and active. After removal of the primary contaminant source, either through remediation efforts or through simple depletion, the direction of diffusion will reverse. Contaminants will diffuse out of the matrix into the fracture network now occupied by uncontaminated water. This will lead to the development of a secondary contaminant source, which might be active for a long period and which will be very difficult and expensive to remediate because of the required long time spans for removing the contaminants from the matrix pore-space (e. g., Germain and Frind, 1989; McKay et al., 1993). Accurate knowledge of effective porosity, therefore, is important for modeling and evaluating the possible apparent retardation of contaminant spread and the possible development of secondary contaminant sources within fractured mudrock saprolite (Toran et al., 1995).

The effective porosity of the Conasauga Group mudrock-saprolite matrix can be considered to consist of a sedimentary porosity and of microfractures. The sedimentary porosity developed following deposition and after experiencing compaction, chemical diagenesis (cementation, dissolution), and weathering to saprolite. Microfractures are considered tectonic in origin and are small enough to be part of the saprolite matrix. The 


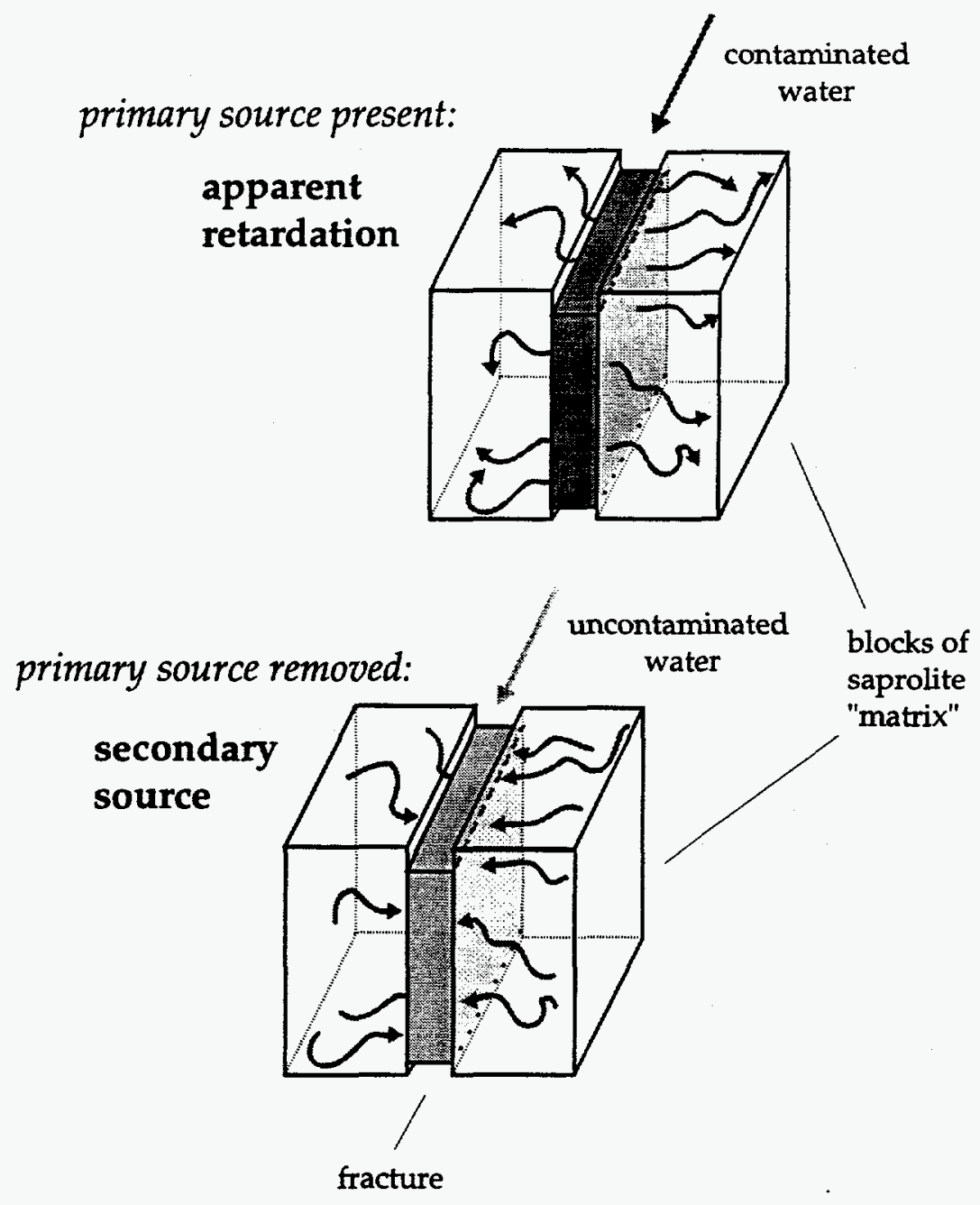

Fig. 3: Schematic block diagrams illustrating the diffusion of contaminant species from a fracture into the surrounding saprolite "matrix" (apparent retardation) and vice versa (secondary contaminant source) (from Dorsch et al., 1996). 
tectonic origin of the microfractures remains speculative, however, because detailed petrographic investigations on bedrock mudrock addressing this question are lacking. Larger microfractures, fractures and voids, abundant in the saprolite mantle, cause the saprolite sample to fall apart into smaller integral matrix blocks. These larger openings within the saprolite mantle were not characterized in this study, but they are important for rapid flow and transport through the saprolite zone (Solomon et al., 1992). That these larger openings are preferential flow paths is indicated by Fe-oxides and Mnoxides coating the walls of the openings, and by translocated clay partially filling the openings (Gwo et al., 1996). The effective porosity data reported in this document are a measure of the space potentially available for diffusive processes within the lowpermeability saprolite matrix. 


\section{PETROPHYSICAL MEASUREMENT TECHNIQUES}

Petrophysical data (effective porosity, specimen grain-density, specimen bulkdensity, and pore-throat sizes) for mudrock saprolite were obtained using state-of-theart laboratory-based measurement techniques. These techniques include helium porosimetry and mercury porosimetry which had been applied previously to finegrained, low-permeability sedimentary rocks (Issler and Katsube, 1994; Loman et al., 1993; Katsube et al., 1992; Katsube and Scromeda, 1991; Katsube and Best, 1992; Soeder, 1988; Dorsch et al., 1996). Both of these techniques generate petrophysical data using a specimen size of less than $10 \mathrm{~g}$.

The specimens used for the petrophysical measurements were dried at temperatures above $100^{\circ} \mathrm{C}$. This was carried out to ensure the determination of all interconnected pore space available for water storage. Drying of specimens above $100^{\circ} \mathrm{C}$ will drive off all pore water in the specimen and all water adsorbed to clay minerals (Scromeda and Katsube, 1993). The drying procedure will not affect the crystal-lattice water, which is part of the clay minerals (Dorsch, 1995). 
Mercury Porosimetry

Principle. Mercury porosimetry involves the forceful injection of a non-wetting liquid (mercury) into a specimen in discrete pressure steps using a mercury porosimeter. The pressures required to force mercury into the specimen correspond to the size of the pore throats and pores (Washburn, 1921; Rootare, 1970; Wardlaw, 1976; KopaskaMerkel, 1988; Wardlaw et al., 1988; Kopaska-Merkel, 1991). With each increasing pressure step, successively smaller pore throats are accessed by mercury. Mercury porosimetry results are displayed as capillary-pressure curves that plot the amount of intruded mercury versus injection pressure (Figure.4). The amount of intruded mercury can be converted to volume of mercury, and the injection pressure can be converted to pore-throat diameters with the Washburn Equation (see below). Mercury porosimetry, therefore, provides quantitative information on the distribution of pore-throat sizes. The sizes of pore throats are important because they control access to pores. Pores of the same size might be accessed through throats of different sizes, but mercury enters the pore space only after a certain injection pressure is reached (Figure 5). The pore space with the larger sized pore throat will be accessed earlier (at a lower injection pressure) than the pore space of equal size but with a smaller pore throat.

Washburn Equation. The Washburn Equation relates the amount of pressure required to force mercury into pores to the pore-throat diameter greater or equal to $d$ (e. g., Katsube and Issler, 1993). Cylindrical pore shapes are assumed to characterize the pore system in mudrock (Katsube and Issler, 1993) and mudrock saprolite, and therefore

$$
\begin{aligned}
& d=(-4 \gamma \cos \theta) / p \\
& \mathbf{d}=\text { throat size } \\
& \gamma=\text { interfacial (surface) tension (for } \mathrm{Hg} / \text { vacuum }=0.48 \mathrm{~N} \cdot \mathrm{m}^{-1} \text { ) } \\
& \theta=\text { contact angle (for } \mathrm{Hg} / \text { vacuum }=30 \text { ) } \\
& \mathbf{p}=\text { intrusion pressure }(\mathrm{MPa}) \text {. }
\end{aligned}
$$

With the help of the Washburn Equation a corresponding pore-throat size can always be calculated from a measured injection pressure.

Procedure. Prior to the petrophysical measurements the specimens were dried in a vacuum oven at a temperature of $105^{\circ} \mathrm{C}$ for $24 \mathrm{~h}$. Following oven drying the specimens were cooled in a desiccator. 

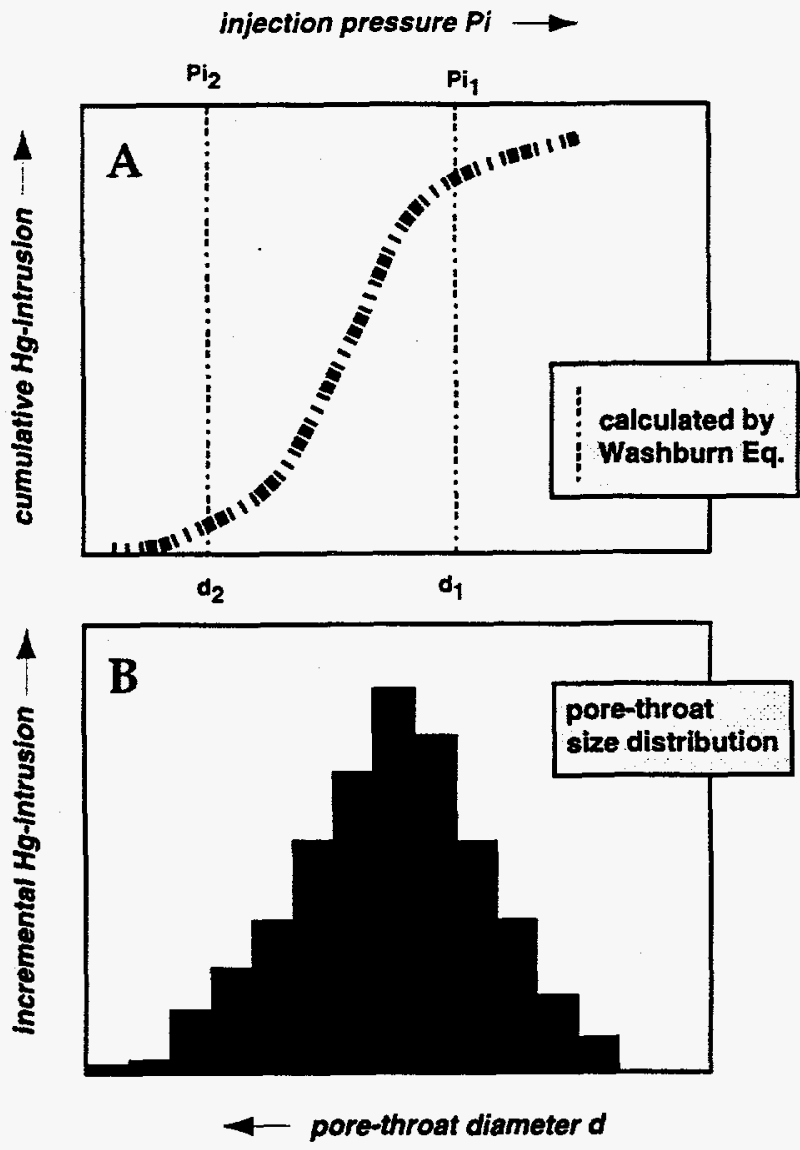

Fig. 4: Capillary-pressure curves, plotting the measured injection pressure and/or the calculated pore-throat diameter versus the amount of intruded mercury (arrows point toward higher values).

A) cumulative intrusion curve, where the total amount of intruded mercury can be read at the right-side end of the curve; $d_{1}$ and $d_{2}$ are pore-throat diameters calculated from intrusion pressures $\mathrm{Pi}_{1}$ and $\mathrm{Pi}_{2}$ using the Washburn Equation. B) incremental intrusion curve showing the amount of mercury intruded at the chosen consecutive pressure steps. Note the pore-throat size distribution obtained in this way (from Dorsch, 1995). 


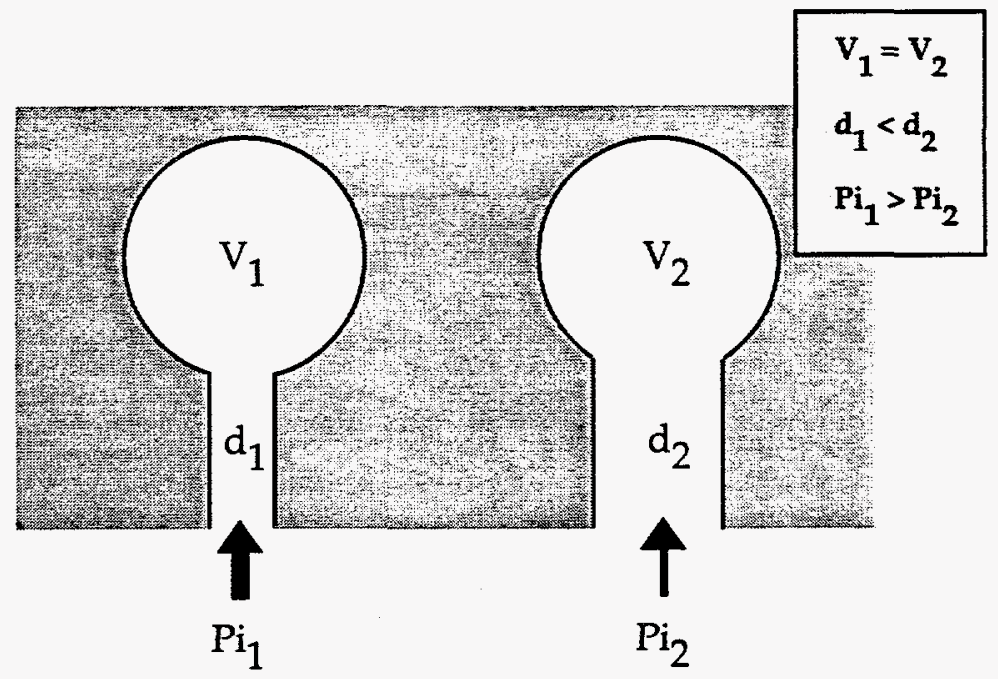

Fig. 5: Illustration of the importance of pore throats for controlling access to pores. Pores of the same size $(V=$ volume $)$ are accessed by pore throats of different sizes $(\mathrm{d}=$ diameter); mercury enters the pore throat only after an injection pressure $(=\mathrm{Pi})$ is reached to force mercury through the pore throat. The pore accessed by the larger pore throat will be invaded earlier at a lower injection pressure than the pore of equal size but with a smaller entry pore-throat (from Dorsch, 1995).

A Micromeritics Autopore 9200 porosimeter was employed for the petrophysical measurements. This mercury porosimeter can generate pressures from 0.14 to $420 \mathrm{MPa}$, which corresponds to an equivalent pore-throat size ranging from 10 to $0.003 \mu \mathrm{m}(10000$ to $3 \mathrm{~nm}$ ). A measurement accuracy for volume of intruded mercury of $\pm 0.0015 \mathrm{~cm}^{3}$ or smaller can be expected (Kopaska-Merkel, 1991).

During the petrophysical measurements the mercury-injection pressure was increased successively in discrete steps (56 steps from 0.14 to $420 \mathrm{MPa}$ ), equally dividing the available pressure range provided by the apparatus on a logarithmic scale. Following each step, time is allotted for equilibration of the system so that no change in volume of mercury taken up by the specimen with time occurs. Equilibrium times were about $40 \mathrm{~s}$ for high pressure steps $(>0.7 \mathrm{MPa})$ and $10 \mathrm{~s}$ for low pressure steps $(<0.7$ MPa) (Katsube and Issler, 1993). For each pressure step the volume of mercury intruding the sample is recorded. Based on the Washburn Equation each discrete pressure step corresponds to a certain pore-throat size. The volume of mercury 
intruding the specimen at each discrete pressure step is converted into the porosity for that pore-throat size and for pores accessed through pore throats of that size (Katsube and Issler, 1993).

Effective Porosity. The effective porosity of the specimen $\left(\phi_{\mathrm{Hg}}\right)$ can be determined by summing up all partial porosity values. Partial porosity $\phi_{\mathrm{a}}$ refers to the porosity contributed by each chosen range of pore-throat sizes (Katsube and Best, 1992). Partial porosity $\phi_{a}$ is calculated for each pore-size range by using the volume of the intruded mercury at this size range and the bulk volume of the sample. The bulksample volume was determined with calculations involving the penetrometer (sample chamber) volume and its weight (with mercury, with sample and mercury). Katsube and Issler (1993) split $\phi_{\mathrm{Hg}}$ into a $\phi_{\mathrm{Hg} 1}$ (sum of all $\phi_{\mathrm{a}}$ from pore sizes $\leq 10 \mu \mathrm{m}$ ) and a $\phi_{\mathrm{Hg} 2}$ (sum of all $\phi_{\mathrm{a}}$ from pore sizes $\leq 250 \mu \mathrm{m}$ ). The reason for this split is that $\phi_{\mathrm{Hg} 2}$ might contain measurement errors induced by the space left between sample and penetrometer wall. $\phi_{\mathrm{Hg} 1}$ is more likely to reflect true effective porosity of the sample for pore sizes of 3 to $10000 \mathrm{~nm}$.

Tabulation of partial porosities provides the distribution of pore-throat sizes for the analyzed specimen. Pore-throat-size data are grouped into size classes, with each decade of the logarithmic pore-throat-size scale being subdivided into 5 size ranges of equal physical spacing (Katsube and Issler, 1993; Katsube and Williamson, 1994).

Geometric Mean of Pore-Throat Sizes. In addition to effective porosity and the range of pore-throat sizes, the geometric mean of the entire pore-throat-size distribution of a specimen can be calculated using the equation (Katsube and Issler, 1993)

$$
\log \left(d_{H_{g}}\right)=\frac{(1 / n) \sum_{i=1}^{n}\left[\phi_{a i} \cdot \log \left(d_{a i}\right)\right]}{\sum_{i=1}^{n} \phi_{a i}}
$$




\section{Helium Porosimetry}

Principle. Helium porosimetry is based on the Boyle-Mariotte Law. A change in gas volume or gas pressure causes a commensurate change in gas pressure or volume, given that the temperature remains constant. Important for helium porosimetry is that an increase in available space causes the gas to expand resulting in the decrease in gas pressure (American Petroleum Institute, 1960; Luffel and Howard, 1988).

Procedure. Prior to the petrophysical measurements, the specimens were dried in a vacuum oven at a temperature of $105^{\circ} \mathrm{C}$ for $24 \mathrm{~h}$. Following oven drying the specimens were cooled in a desiccator.

For helium porosimetry the specimen is placed into a steel chamber of known volume. Helium isothermally expands into the chamber from a reservoir of known volume and pressure until equilibrium pressure is reached $(30 \mathrm{~min}$ to $1 \mathrm{~h}$ ). From the new gas pressure the grain volume can be calculated. The bulk volume of the sample is then determined by immersion of the specimen in mercury (measuring volume of mercury displaced from a pycnometer, or measuring the buoyant force, based on the Archimedes principle).

Effective Porosity. Effective porosity is calculated by subtracting the grain volume from the bulk volume, and dividing the result by the bulk volume of the specimen.

$$
\phi_{\text {He }}=\left(V_{\text {bimm }}-V_{g}\right) / V_{\text {bimm }}
$$

$\phi_{\mathrm{He}}=$ effective porosity (determined with helium porosimetry) $\mathrm{V}_{\mathrm{g}}=$ grain volume

$\mathbf{v}_{\text {bimm }}=$ bulk specimen-volume measured with mercury immersion. 


\section{SAMPLING}

Cores

Saprolite specimens for the petrophysical measurements were obtained from coreholes drilled into the Whiteoak Mountain thrust sheet on the ORR. The drill site is situated within Bear Creek Valley (Figure 6) along strike to the southeast of the Y-12 Plant. Core material was available from coreholes GW-821, GW-822, and GW-823. The coreholes were drilled in June of 1994 using Rotasonic dry drilling for the regolith interval (soil and saprolite) and rotary drilling with water for bedrock (Moline and Schreiber, 1995). The cores are nearly complete and undisturbed through the saprolite mantle and are described in detail by Schreiber (1995) and Moline and Schreiber (1995). The cores were laid out in sequence with increasing depth in Building 7042 ('core barn') at X-10 for sampling. The soil zone in the cores is thin and reaches to about $15 \mathrm{~cm}$ below the ground surface (Schreiber, 1995; M. Elless, pers. comm.).

\section{Sampling Intervals}

The cores were inspected and sampling intervals were chosen (Figure 7) based on the following criteria: 1) incorporation of the complete weathering zone above bedrock, 2) availability of multiple macroscopically homogeneous specimens (analysis specimens; duplicate specimens for use in case of analysis-specimen failure), 3) absence of excessive deformation, and 4) availability of appropriate lithologies (groundmass and mudrock fragments, see below). Sampling intervals for saprolite groundmass were generally $\leq 7$ $\mathrm{cm}$ in length, whereas sampling intervals for saprolite mudrock-fragments were generally $\leq 15 \mathrm{~cm}$ in length. The code for the sampling intervals includes the corehole designation followed by an interval number (e. g., GW-823-7). The interval number is based on sequentially numbering the core intervals as used by Schreiber (1995) and Moline and Schreiber (1995) for core description. Appendix I provides an overview of sampling intervals, their code, drill depth (the median of the chosen sampling interval is used), and specimen type. Overall, 10 sampling intervals were selected from cores GW-822 and GW-823.

\section{Saprolite Specimens}

Specimens for petrophysical analysis were selected from the chosen sampling intervals, with each sampling interval providing one specimen pair for analysis (one 


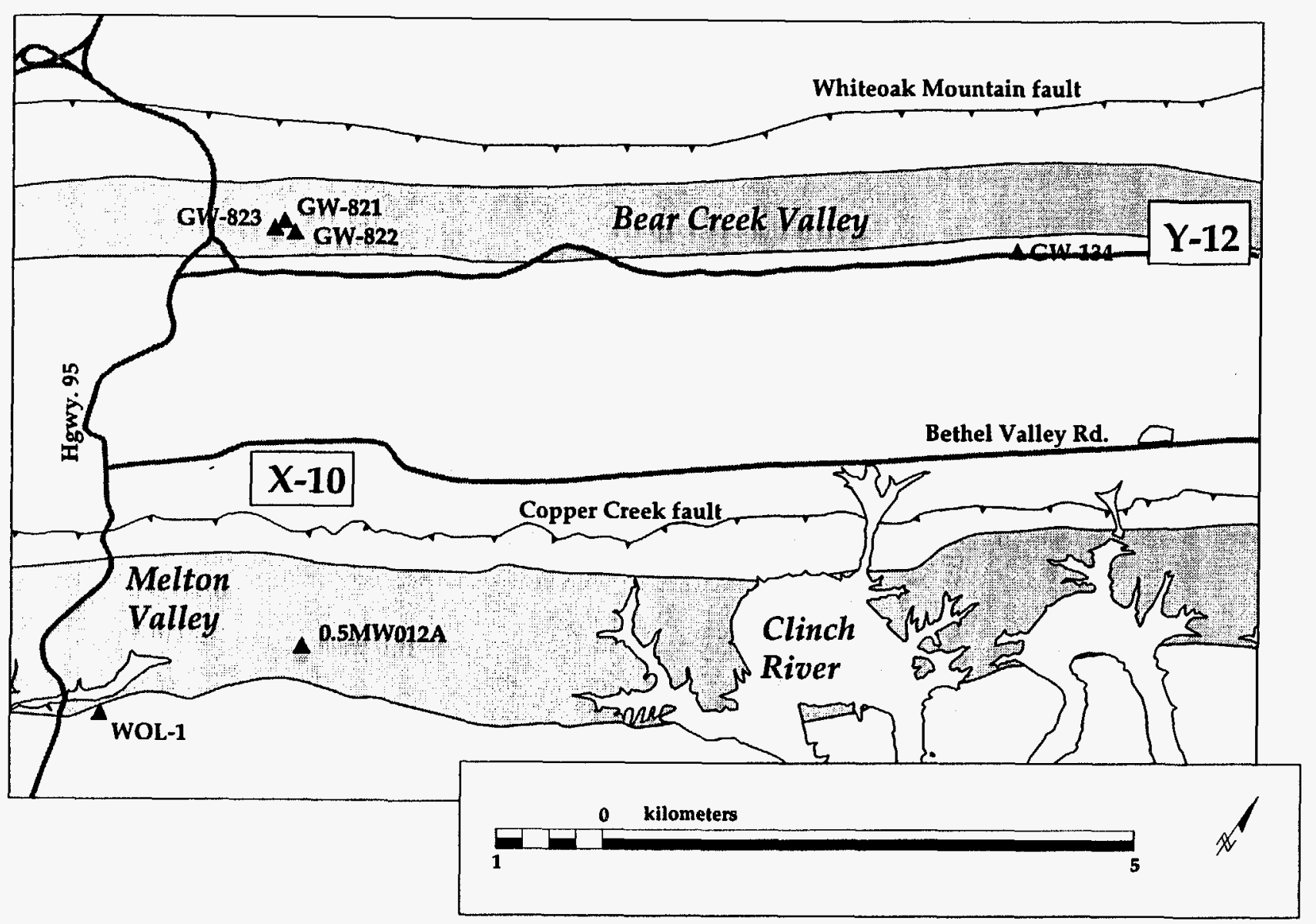

Fig. 6: Generalized location map. Dark stippled bands traversing the ORR outline the mudrock-dominated part of the Conasauga Group in outcrop. Barbed solid black lines indicate the location of the Whiteoak Mountain fault and of the Copper Creek fault, whereas stippled lines indicate major roads. Triangles refer to the location of coreholes from which specimens were selected: GW-821, $-822,-823$ for mudrock saprolite of the Nolichucky Shale, corehole GW-134 for mudrock (bedrock) of the Nolichucky Shale.

(modified from Dorsch et al., 1996; based on Hatcher et al., 1992). 


\section{7}

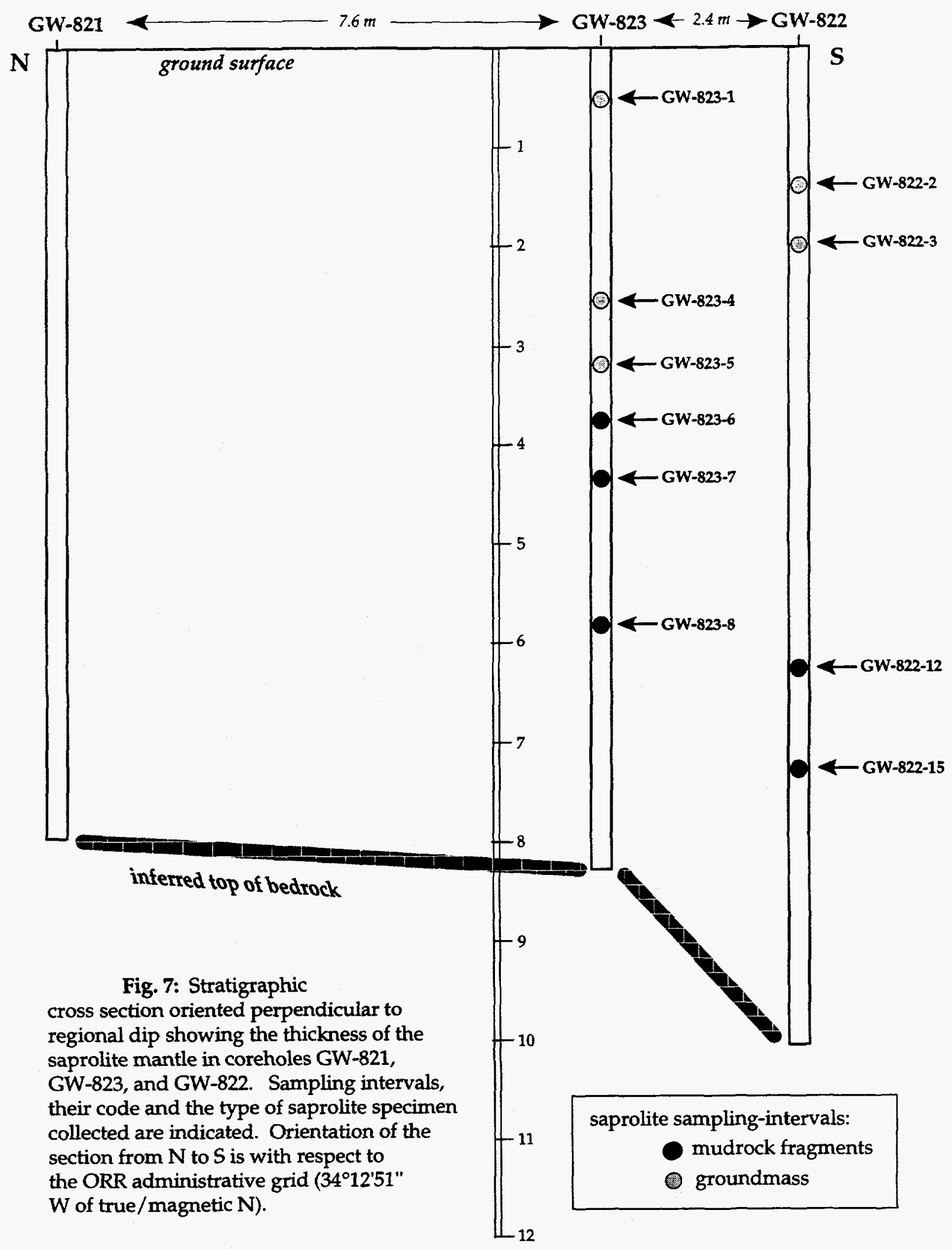

m 
specimen for helium porosimetry and one specimen for mercury porosimetry) and additional duplicate specimens for use in case of analysis-specimen failure. All specimens were of irregular shape. Overall, a total of 20 specimens were analyzed ( 10 each with mercury and helium porosimetry).

The saprolite cores were divided into two components: 1) groundmass, and 2) sedimentary rock fragments. Groundmass consists of heavily weathered mudrock material which still has coherence and shows original sedimentary and tectonic structures. Saprolite groundmass is plastic and easily deformable when moist or wet, and is friable and crumbly when dry. The groundmass constitutes most of the saprolite mantle and contains more rigid and harder, well defined sedimentary rock fragments. The vast majority of these "floating" fragments are mudrock, but also a few small siltstone/fine sandstone and rare larger limestone fragments were encountered. The mudrock fragments are similar to mudrock (bedrock) in appearance, but are noticeably softer when scratched with a knife. It was often observed that a larger piece of saprolite groundmass contained a more solid and harder mudrock fragment in its center, after the friable groundmass mantle was crumbled away.

Mudrock-Fragment Specimens. Mudrock ${ }^{(1)}$ fragments for analysis were pulled directly out of the moist saprolite groundmass. In the laboratory, the surface-dry fragments were carefully cleaned using dry and slightly damp kimwipe ${ }^{\circledR}$ tissues, a toothbrush, and a small knife. No water was used for specimen cleaning (note: earlier sampled material was cleaned under running tap water, but this caused the mudrock fragments to become too fragile and the procedure was then discontinued). The mudrock-fragment specimens were $\leq 10 \mathrm{~g}$. Ten specimens were used for petrophysical analysis, with 57 additional specimens retained as duplicates for use in case of analysis-specimen failure.

Groundmass Specimens. Groundmass specimens for analysis were retrieved from core segments $\leq 7 \mathrm{~cm}$ in length. The segments were predominantly moist at the time of sampling but also two dry segments were used. The segments were put into an oven for

(1) mudrock refers to all types of fine-grained siliciclastic rock, following the definition of Blatt et al. (1980); however, sampled material for petrophysical analysis (saprolite and bedrock) were predominantly mudstone and claystone, with subordinate mud-shale and clayshale; no siltstone, silt-shale, or marlstone specimens were used for analysis. 
$48 \mathrm{~h}$ and dried at a temperature of $60^{\circ} \mathrm{C}$. The result were dry and hardened but still brittle and friable core segments of saprolite groundmass. The core segments were then carefully broken into smaller coherent units using pliers, a knife and a screw driver. The smaller units were then prepared to size and cleaned under a laboratory hood using dry kimwipe ${ }^{\circledR}$ tissues, toothbrush, and knife. No water was used for specimen cleaning. The groundmass specimens were $\leq 8.55 \mathrm{~g}$. Specimens with macroscopic cracks were discarded. All saprolite-groundmass specimens represent small coherent units devoid of visible cracks and fractures. Ten specimens were used for petrophysical analysis, with eleven additional specimens and several core segments retained as duplicates for use in case of analysis-specimen failure. 


\section{GRAIN-DENSITY AND BULK-DENSITY DATA}

\section{Specimen Bulk-Density}

Bulk-density data was obtained for the saprolite specimens by mercury porosimetry. The results are displayed in Table 1 and shown in a scatter plot (Figure 8).

Saprolite mudrock-fragments display an arithmetic mean of $2.44( \pm 0.07) \mathrm{g} \cdot \mathrm{cm}^{-3}$ (Appendix II). The values range from a minimum of $2.36 \mathrm{~g} \cdot \mathrm{cm}^{-3}$ to a maximum of 2.53 $\mathrm{g} \cdot \mathrm{cm}^{-3}$. The scatter of the data, as apparent from Figure 8 , is small.

The results for the saprolite-groundmass specimens are markedly different, however. All values are below $2.00 \mathrm{~g} \cdot \mathrm{cm}^{-3}$, with a minimum of $1.48 \mathrm{~g} \cdot \mathrm{cm}^{-3}$ and a maximum of $1.91 \mathrm{~g} \cdot \mathrm{cm}^{-3}$ (Table 1). The arithmetic mean is $1.75( \pm 0.19) \mathrm{g} \cdot \mathrm{cm}^{-3}$ (Appendix II). The scatter of the data is considerably larger than the scatter for the saprolite mudrock-fragments (Figure 8).

Table 1: Data on specimen grain density $\delta_{\mathrm{He}}$ and specimen bulk-density $\delta_{H_{\mathrm{g}}}$ for mudrock-saprolite specimens, Bear Creek Valley on the ORR.

\begin{tabular}{cccc} 
sampling interval & $\delta_{\mathrm{He}}\left[\mathrm{g} \cdot \mathrm{cm}^{-3}\right]$ & $\delta_{\mathrm{Hg}}\left[\mathrm{g} \cdot \mathrm{cm}^{-3}\right]$ & specimen type \\
\hline GW-822-12 & 2.81 & 2.50 & mudrock fragment \\
GW-822-15 & 2.81 & 2.53 & mudrock fragment \\
GW-823-6 & 2.78 & 2.36 & mudrock fragment \\
GW-823-7 & 2.78 & 2.39 & mudrock fragment \\
GW-823-8 & 2.80 & 2.40 & mudrock fragment \\
& & & \\
GW-822-2 & 2.90 & 1.81 & saprolite groundmass \\
GW-822-3 & 2.87 & 1.92 & saprolite groundmass \\
GW-823-1 & 2.76 & 1.48 & saprolite groundmass \\
GW-823-4 & 2.70 & 1.64 & saprolite groundmass \\
GW-823-5 & 2.72 & 1.91 & saprolite groundmass
\end{tabular}



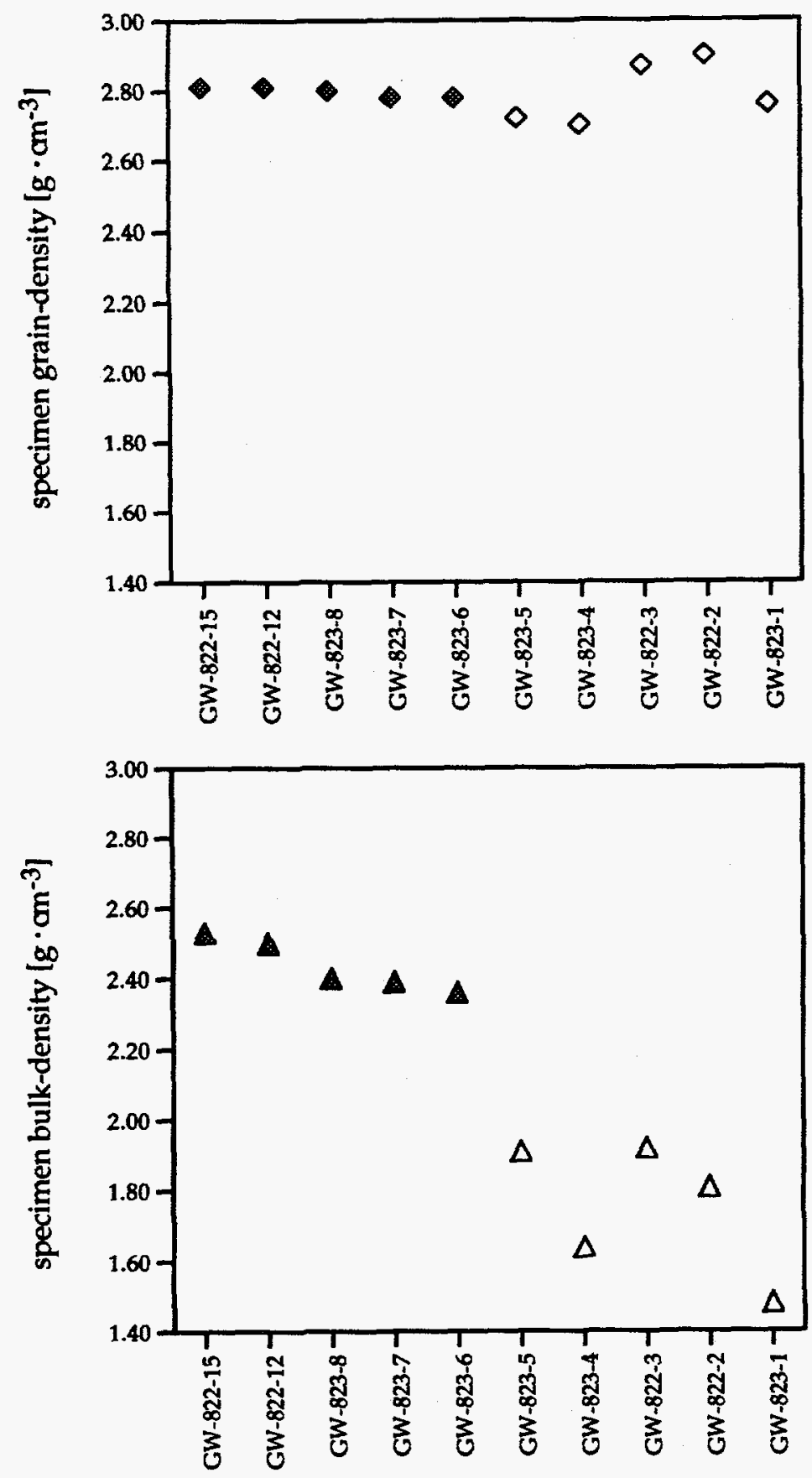

A mudrock fragment (saprolite)

$\triangle \quad$ groundmass

(saprolite)

sampling interval

Fig. 8: Density data from saprolite specimens (mudrock fragments and groundmass), Bear Creek Valley on the ORR. 


\section{Specimen Grain-Density}

The data on grain density were obtained during helium porosimetry for specimens from the same sampling intervals as the data for bulk density. Overall, the specimen grain-density data are higher than the specimen bulk-density data.

For saprolite mudrock-fragments the values range from $2.78 \mathrm{~g} \cdot \mathrm{cm}^{-3}$ to $2.81 \mathrm{~g} \cdot \mathrm{cm}^{-3}$, with an arithmetic mean of $2.80( \pm 0.02) \mathrm{g} \cdot \mathrm{cm}^{-3}$ (Table 1; Appendix II). The data show only a minimal scatter and are virtually identical (Figure 8).

The saprolite groundmass-specimens display an arithmetic mean of $2.79( \pm 0.09)$ $\mathrm{g} \cdot \mathrm{cm}^{-3}$ (Appendix II) with a minimum value of $2.70 \mathrm{~g} \cdot \mathrm{cm}^{-3}$ and a maximum value of 2.90

$\mathrm{g} \cdot \mathrm{cm}^{-3}$ (Table 1). The scatter in the data is larger than for the saprolite mudrockfragments, but is still small. 


\section{PORE-THROAT-SIZE DATA}

Quantitative data on the sizes of pore throats and their distribution were obtained for all analyzed saprolite specimens by mercury porosimetry. The data are tabulated in detail in Appendix III, and the resulting pore-throat-size distribution curves for each saprolite specimen are shown in Appendix IV.

\section{Saprolite Mudrock-Fragments}

Pore-throat-size distribution curves of saprolite mudrock-fragments (Figure 9; Appendix IV) are unimodal to bimodal and are skewed to the right (steeper slopes toward smaller throat sizes together with long and gentle slopes toward larger throat sizes). The pore-throat-size distributions show zero values at the higher end of the tested size spectrum and terminate abruptly at about $3 \mathrm{~nm}$ at the lower end of the tested size spectrum (Figure 9, Appendices III, IV). Therefore, the smallest pore-throat sizes encountered are in the size class with a mean of $3.2 \mathrm{~nm}$, whereas the largest porethroat sizes are in the size classes characterized by means of $794 \mathrm{~nm}, 1259 \mathrm{~nm}$, and $3162 \mathrm{~nm}$ (there can be smaller outliers) (Figure 9; Appendix III). The modes of the distribution curves reside within different size classes for different specimens, but fall consistently between $5 \mathrm{~nm}$ and $20 \mathrm{~nm}$. The geometric means for the entire pore-throatsize distribution of saprolite mudrock-fragments are very similar and range from 18 to $28 \mathrm{~nm}$ (Appendix III). It is apparent from the distribution curves that the vast majority of the pores are accessed by pore throats smaller than $100 \mathrm{~nm}$ in size (Figure 9; Appendix IV).

\section{Saprolite Groundmass}

Pore-throat-size distribution curves of saprolite-groundmass specimens (Figure 9; Appendix IV), in contrast, are skewed toward the left (steeper slopes toward larger throat sizes with long and gentle slopes toward smaller throat sizes). Distribution curves commonly are unimodal (with smaller secondary modes) with pronounced modes

Fig. 9: Typical pore-throat-size distribution curves for saprolite developed from mudrock of the Nolichucky Shale, Bear Creek Valley on the ORR. Vertical axis shows partial effective porosity in \%, horizontal axis shows size of pore throats in nanometers. A, B, C show curves for saprolite mudrock-fragments, $D$ and $E$ show curves for saprolite-groundmass specimens. 


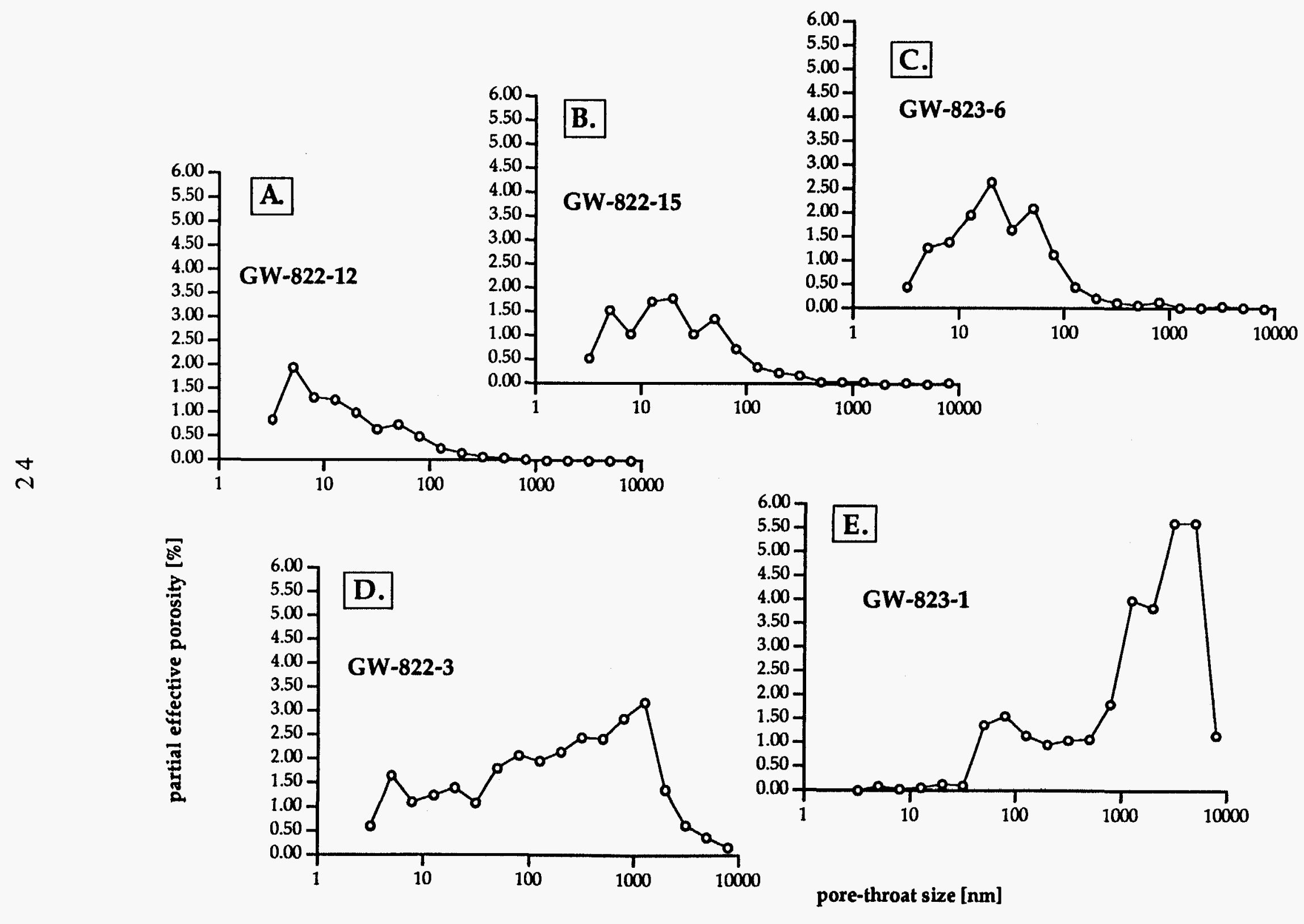


(Appendix IV). The modes reside within the size class with a mean of $1259 \mathrm{~nm}$, with one example displaying the mode between 3000 and $5000 \mathrm{~nm}$ (Appendix III). Geometric means for the entire pore-throat-size distribution of saprolite-groundmass specimens are considerably higher than for saprolite mudrock-fragments and show a wide variation. The values range from 182 to $2201 \mathrm{~nm}$, with the vast majority of the values being above $850 \mathrm{~nm}$. The smallest pore-throat sizes encountered are in the size class with the mean of $3.2 \mathrm{~nm}$ (one exception with $7.9 \mathrm{~nm}$ ), as was the case for saprolite mudrock-fragments (Figure 9; Appendices III, IV). At the higher end of the analyzed size spectrum, however, no zero values are reached and the curves appear to terminate abruptly at the reported size class with $7943 \mathrm{~nm}$ as a mean. The curves show that the vast majority of the pores are accessed by pore throats larger than $100 \mathrm{~nm}$ in size, in direct contrast to the data reported for saprolite mudrock-fragments (Figure 9; Appendix IV). 


\section{EFFECTIVE POROSITY DATA}

\section{Helium Porosimetry}

Effective porosity values for saprolite specimens determined with helium porosimetry are shown in Table 2 . The accuracy of the measurements is estimated to be within 10 to $20 \%$ of the measured value.

For saprolite mudrock fragments the values range from 13.5 to $18.1 \%$, with a mean of $16.1( \pm 1.8) \%$ (Table 2; Appendix II). The scatter of the data is very small (Figure 10).

The values obtained for saprolite-groundmass specimens, in contrast, are markedly higher with a minimum of $31.7 \%$ and a maximum of $51.6 \%$ (Table 2). The data also display a considerably larger scatter, with a mean of $39.0( \pm 7.5) \%$ (Figure 10; Appendix II).

Table 2: Data on effective porosity of saprolite specimens; $\phi \mathrm{He}$ refers to data obtained with helium porosimetry, whereas $\phi_{\mathrm{Hg}}$ refers to data obtained with mercury porosimetry (Hg1: for pore throats $\leq 10 \mu \mathrm{m}, \mathrm{Hg} 2$ for pore throats $\leq 250 \mu \mathrm{m}$ ).

\begin{tabular}{ccccc} 
sampling interval & $\phi_{\mathrm{He}}[\%]$ & $\phi_{\mathrm{Hg} 1}[\%]$ & $\phi_{\mathrm{Hg} 2}[\%]$ & specimen type \\
\hline GW-822-12 & 16.7 & 8.8 & 9.2 & mudrock fragment \\
GW-822-15 & 13.5 & 10.7 & 11.2 & mudrock fragment \\
GW-823-6 & 18.1 & 13.7 & 14.0 & mudrock fragment \\
GW-823-7 & 15.1 & 12.2 & 12.8 & mudrock fragment \\
GW-823-8 & 17.3 & 9.5 & 10.1 & mudrock fragment \\
& & & & \\
GW-822-2 & 38.9 & 22.0 & 23.7 & saprolite groundmass \\
GW-822-3 & 33.6 & 28.5 & 29.3 & saprolite groundmass \\
GW-823-1 & 51.6 & 29.5 & 37.5 & saprolite groundmass \\
GW-823-4 & 39.3 & 26.7 & 38.2 & saprolite groundmass \\
GW-823-5 & 31.7 & 27.2 & 40.0 & saprolite groundmass
\end{tabular}



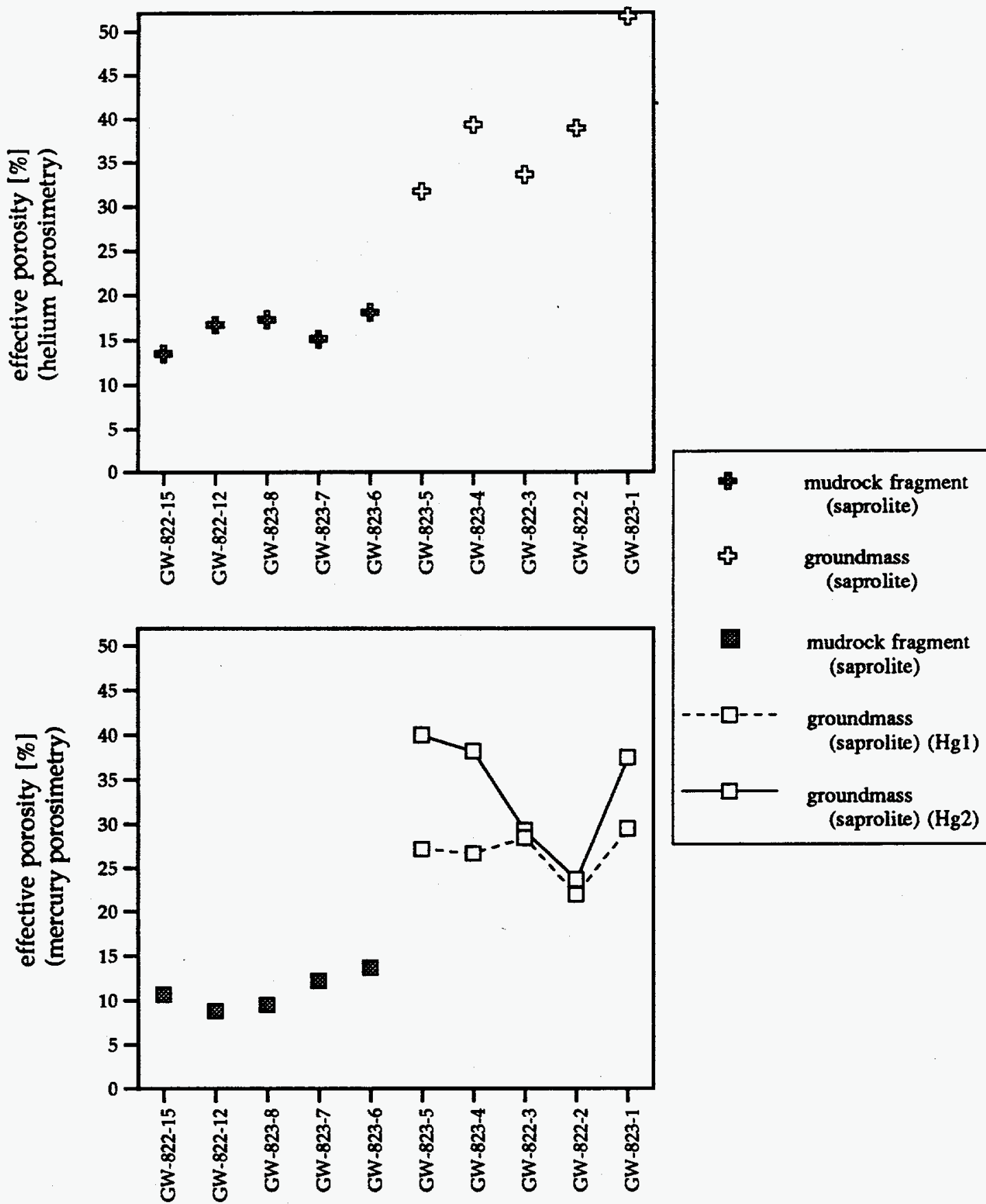

sampling interval

Fig. 10: Effective porosity data from saprolite specimens (mudrock fragments and groundmass), Bear Creek Valley on the ORR. Helium-porosimetry data are shown in the upper graph, mercury-porosimetry data are shown in the lower graph. 


\section{Mercury Porosimetry}

Effective porosity data obtained with mercury porosimetry are reported in two forms (Table 2). Hg1-data refer to pores accessed by pore throats $\leq 10000 \mathrm{~nm}$, whereas $\mathrm{Hg}$ 2-data include pores accessed by pore throats $\leq 250000 \mathrm{~nm}$. Hg1-data are commonly judged as more reliable because they are less likely to include measurement errors than $\mathrm{Hg}$ 2-data (Katsube and Issler, 1993). Hg1-data are used for saprolite mudrockfragments. The shift of the pore-throat size spectrum toward larger sizes for saprolite groundmass (see above) makes it advisable, however, to use Hg2-data for the saprolitegroundmass specimens. This entails the possibility, though, that added effective porosity is incorporated due to measurement errors. The small difference between $\mathrm{Hg} 1-$ values and $\mathrm{Hg}$ 2-values for saprolite mudrock-fragments (Table 2) indicates that most pore space is characterized by entry pore-throats $\leq 10000 \mathrm{~nm}$ in size. Two specimens of saprolite groundmass (GW-822-2, GW-822-3) show similarly small differences, again indicating that most interconnected pore space is accessed by pore throats $<10000 \mathrm{~nm}$ in size. The larger differences between $\mathrm{Hg}$ 1-values and $\mathrm{Hg}$ 2-values for some saprolitegroundmass specimens (GW-823-1, GW-823-4, GW-823-5) (Table 2; Figure 10) simply reflect that a significant portion of pores are accessed by pore-throats in excess of 10000 nm. Hg1-data are plotted for saprolite mudrock-fragments in Figure 10, whereas both $\mathrm{Hg} 1$ - and $\mathrm{Hg} 2$-data are shown for saprolite-groundmass specimens, with $\mathrm{Hg} 2$-data considered to more likely reflect true effective porosity (see further discussion below). As for helium porosimetry, the accuracy of the measurements is estimated to be within 10 to $20 \%$ of the measured value.

Saprolite mudrock-fragments show a mean effective porosity of $11.0( \pm 2.0) \%$, with minimum and maximum values of $8.8 \%$ and $13.7 \%$, respectively (Table 2; Appendix II). The scatter of the data is small (Figure 10).

Effective porosity data $(\mathrm{Hg} 2)$ for saprolite-groundmass specimens, on the other hand, are considerably larger, ranging from 23.7 to $40.0 \%$, with a mean of $33.7( \pm 7.0) \%$ (Table 2; Appendix II). The scatter of the data, furthermore, is considerably larger than for effective porosity data of saprolite mudrock-fragments (Figure 10). Hg1 effective porosity data show maximum and minimum values of $29.5 \%$ and $22.0 \%$, with a mean of $26.8( \pm 2.9) \%$ (Table 2; Appendix II). 


\section{Calculated Interval Effective Porosity}

The saprolite mantle above bedrock is characterized by heavily weathered saprolite groundmass which contains less weathered fragments (mostly mudrock). For selected intervals of the saprolite mantle (Figure 11), matrix effective porosities were calculated using helium-porosimetry data. These calculations are based on:

1) using the measured effective porosity value of the analyzed specimen type from the selected sampling interval (either saprolite mudrock-fragment or saprolite groundmass effective porosity),

2) assuming the complementary effective porosity value for the specimen type not analyzed from the selected sampling interval (either saprolite groundmass or saprolite mudrock-fragment effective porosity), and

3) estimating the relative proportion of the two saprolite specimen-types (groundmass and mudrock-fragment) over the length of the chosen sampling interval.

From the relative proportion of mudrock fragments and groundmass and their effective porosities, the interval effective porosity can be calculated. The data used for the calculation of interval effective porosities are provided in Appendix V.

As an example, consider saprolite sampling-interval GW-823-4. It is composed to approximately $97 \%$ of groundmass and to $3 \%$ of mudrock-fragments (Appendix V). A measured effective porosity value of $39.3 \%$ is available for the groundmass of this sampling interval. A complementary effective porosity value for mudrock fragments is not available and must be assumed. A value of $18.1 \%$ was chosen, because this is the highest measured mudrock fragment effective porosity value from sampling zones below sampling interval GW-823-4. This value is interpreted to best approximate the effective porosity of saprolite mudrock-fragments within sampling interval GW-823-4. The two effective porosity values are then multiplied by the estimated respective proportions of the specimen types within the chosen sampling interval, resulting in an effective porosity contribution of $38.12 \%$ from saprolite groundmass and of $0.54 \%$ from saprolite mudrock fragments. Adding up the two values finally provides the effective porosity of the saprolite matrix of the chosen sampling interval of $38.7 \%$ excluding macroscopically visible fractures.

Note that there also can be carbonate-rock fragments (predominantly rare, but up to $10 \%$ in one interval) within the saprolite groundmass. The observed carbonaterock fragments, however, are fresh, hard and "tight" indicating low levels of effective porosity. Because of their "tightness" and scarcity they are judged to be a negligible 


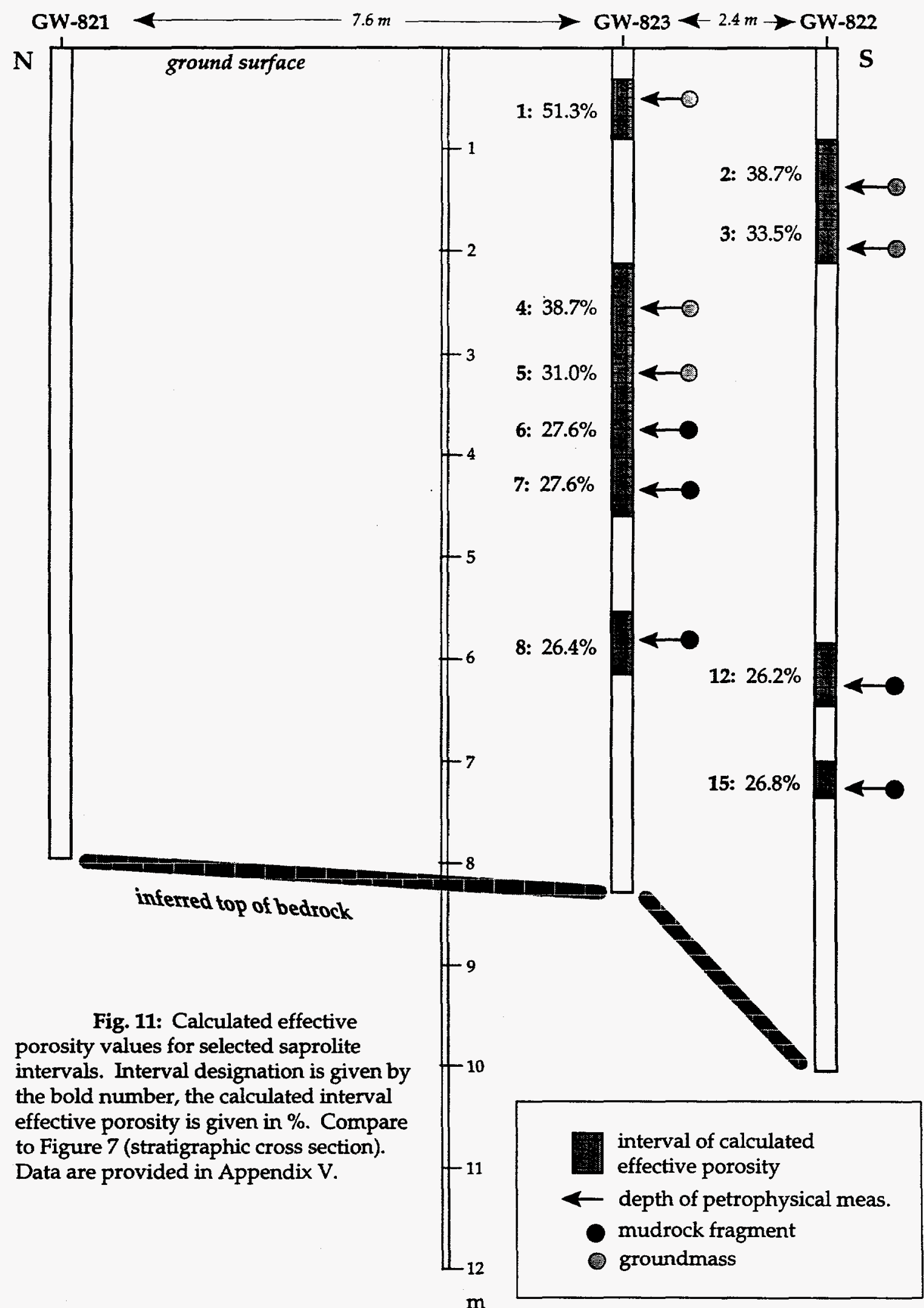


addition to overall saprolite-matrix effective porosity.

The results show that effective porosities of saprolite matrix for the chosen intervals range from a maximum $51.3 \%$ to a minimum of $26.2 \%$ (Figure 11; Appendix V). 


\section{COMPARISON TO BEDROCK AND DISCUSSION}

The discussion section will include a comparison of the saprolite petrophysical data with petrophysical data obtained for bedrock specimens from the Nolichucky Shale within Bear Creek Valley (Dorsch et al., 1996). The Nolichucky Shale within Bear Creek Valley represents the parent material of the mudrock saprolite analyzed for this report. Bedrock petrophysical data are summarized in Appendix VI.

\section{Specimen-Density Data}

Grain-Density Data. Grain-density data for mudrock specimens from bedrock (Nolichucky Shale) display a mean of $2.77( \pm 0.03) \mathrm{g} \cdot \mathrm{cm}^{-3}$ (Appendix II). These values and their negligible scatter are essentially identical to the values reported for saprolite mudrock-fragments $\left(2.80[ \pm 0.02] \mathrm{g} \cdot \mathrm{cm}^{-3}\right)$ (Figure 12). Furthermore, the arithmetic mean for saprolite groundmass-specimens $\left(2.79[ \pm 0.09] \mathrm{g} \cdot \mathrm{cm}^{-3}\right)$ conforms to the means for mudrock fragments (bedrock and saprolite) (Appendix II). The scatter for groundmass specimens, however, is larger, although it is still small. This noticeable increase in scatter is interpreted to reflect the more severe chemical weathering experienced by the saprolite groundmass. The two grain-density values for saprolite groundmass above the normal trend (GW-822-3, GW-822-2) might indicate the addition of more dense mineral phases or the loss of some less dense mineral phases, again reflecting the influence of chemical weathering on the grain material and/or cement. At present, there is no petrographic information available to evaluate what solid material was lost or added during weathering and the development of saprolite. The most likely explanation is the addition of denser mineral phases, such as Fe-oxides and Mn-oxides. This explanation is supported by other observations within the upper, more weathered zones of saprolites developed from the Conasauga Group on the ORR (S. Y. Lee, pers. comm.). Overall, however, the solid material of the specimens appears to have remained similar for bedrock and saprolite mudrock-fragments, with some smaller changes for saprolite groundmass.

Bulk-Density Data. Bulk-density data, in contrast, fall into three distinct groups. Mudrock specimens from bedrock display the highest values with an arithmetic mean of

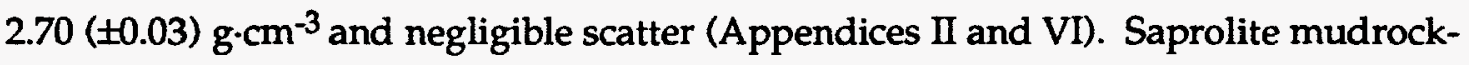
fragments show lower values with a somewhat larger (but still small) scatter (2.44 $[ \pm 0.07] \mathrm{g}^{-3} \mathrm{~cm}^{-3}$ ), and saprolite-groundmass specimens display the lowest values with a distinctly larger scatter $1.75[ \pm 0.19] \mathrm{g} \cdot \mathrm{cm}^{-3}$ ) (Figure 12; Appendix II). This trend toward 

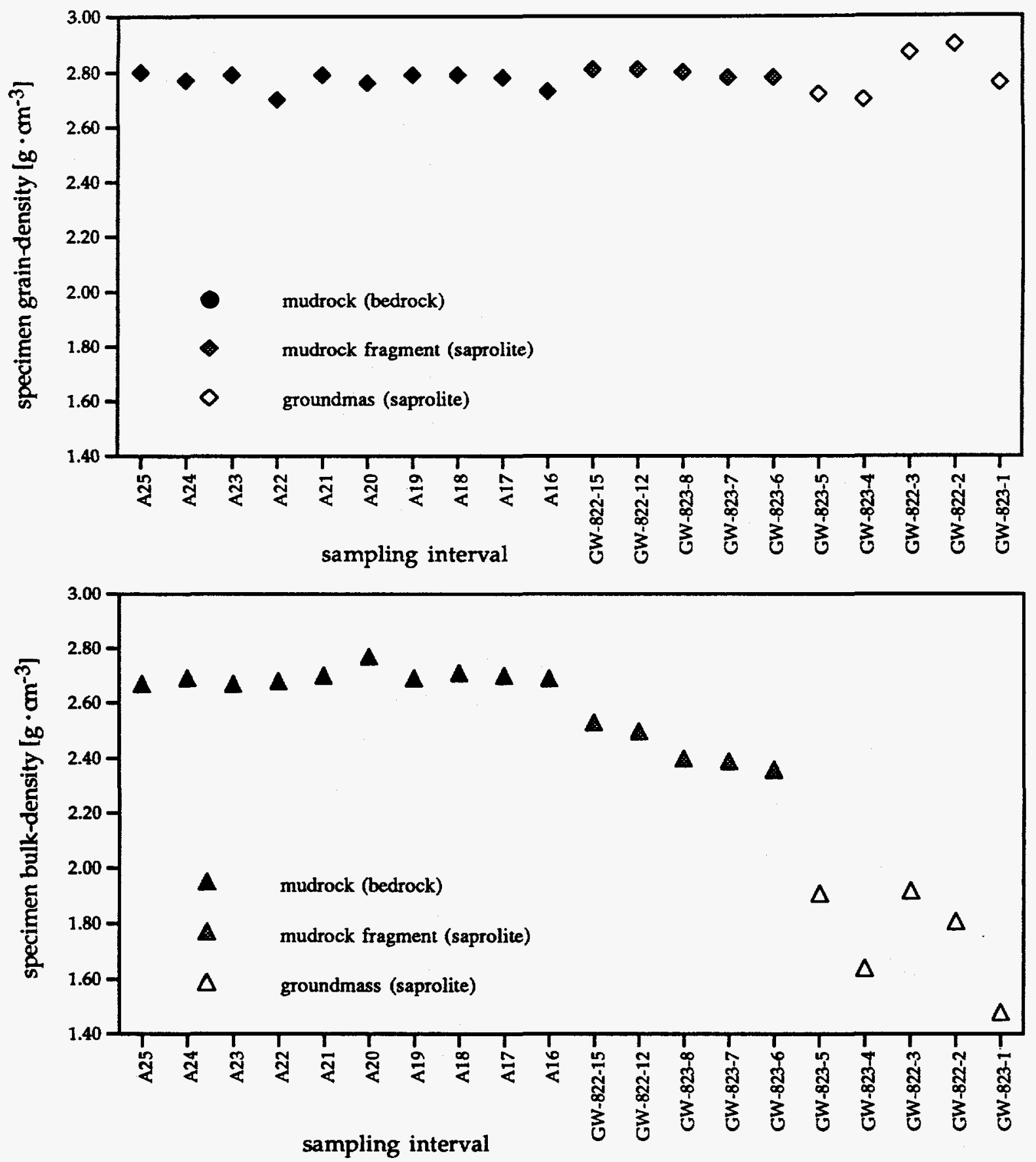

Fig. 12: Comparison of bulk and grain densities from saprolite specimens (mudrock fragments and groundmass) and Nolichucky Shale specimens (bedrock), Bear Creek Valley on the ORR. 
lower bulk-density values together with enlarging scatter (Figure 12) is interpreted to reflect the increasing effect of weathering. Void space per bulk volume of specimen material expands from bedrock mudrock, through saprolite mudrock-fragments, to saprolite-groundmass specimens. The increased effect of weathering might include a loss of cement, loss of some grain material, and a loosening of the fabric. This latter aspect results in the significantly less cohesive and more friable (but still cohesive) nature of the saprolite groundmass. The most noticeable loss is probably that of carbonate cement and carbonate grains (Lietzke et al., 1992; S. Y. Lee, pers. comm.). Changes in bulk density are considerably more drastic when compared to changes in grain density, reflecting a significant increase in void space but only a comparatively less notable change in the nature of the remaining solid mineral phases.

Density Data with Depth. Density data plotted against depth (Figure 13) again show the general uniformity of the specimen grain-density values from bedrock toward the top saprolite zone. The distinct veering toward lower values for specimen bulkdensity and the increased difference from grain-density data from the same sampling interval is interpreted to characterize a weathering profile from bedrock toward the shallow saprolite zones.

\section{Pore-Throat Size Data}

Mudrock specimens from the Nolichucky Shale (bedrock) from Bear Creek Valley display unimodal (rarely bimodal, with strongly weaker secondary modes) pore-throatsize distribution curves skewed toward the right. All curves terminate abruptly at about $3 \mathrm{~nm}$, and the vast majority of pores is accessed by pore throats $<100 \mathrm{~nm}$ in size (Dorsch et al., 1996; Figure 14). These characteristics match the characteristics of saprolite mudrock-fragments. The pore-throat-size distribution curves of specimens GW-822-12 and GW-823-8 especially resemble in overall shape and location of modes ( $5 \mathrm{~nm}$ size class) the pore-throat-size distribution curves of bedrock specimens (Appendix IV; Figure 14). Important differences are, however, that the area under the curves is significantly larger for saprolite mudrock-fragments than for bedrock mudrock (Figure 14). This reflects the higher effective porosities of saprolite mudrock-fragments. Commensurate with this increase in area under the distribution curves, the overall throat-size spectrum shifts to the right and toward larger throat sizes (Figure 14), exemplified by the shift of modes from $5 \mathrm{~nm}$ (bedrock specimens; GW-822-12, GW-8238) to $20 \mathrm{~nm}$ (GW-823-7, GW-822-15, GW-823-6). 


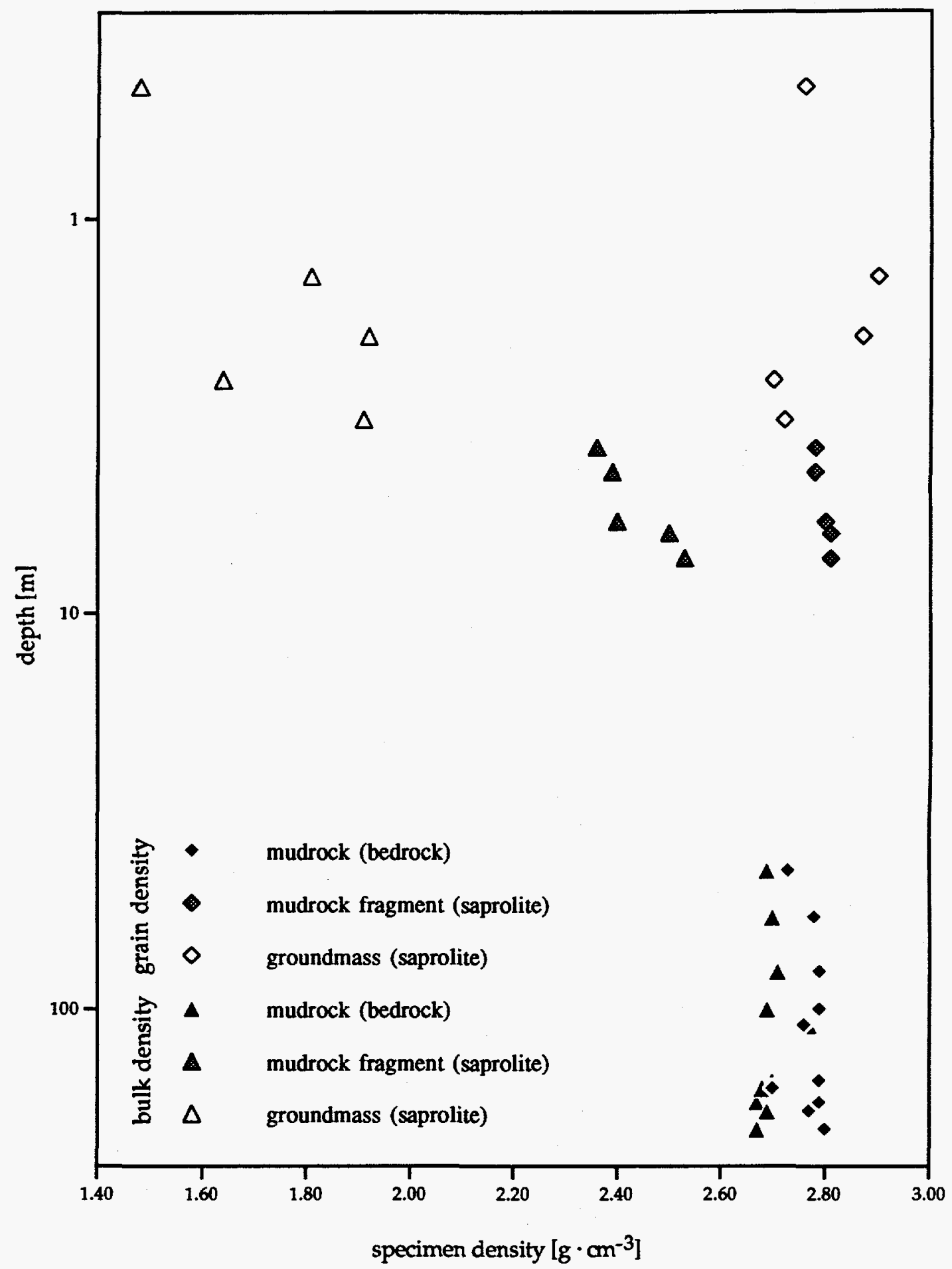

Fig. 13: Specimen density-pairs with depth for Nolichucky Shale and saprolite specimens, Bear Creek Valley on the ORR. Maximum depth is $201.19 \mathrm{~m}$, minimum depth is $0.46 \mathrm{~m}$; depth is given as below ground surface (note log-scale on depth axis). 
苋

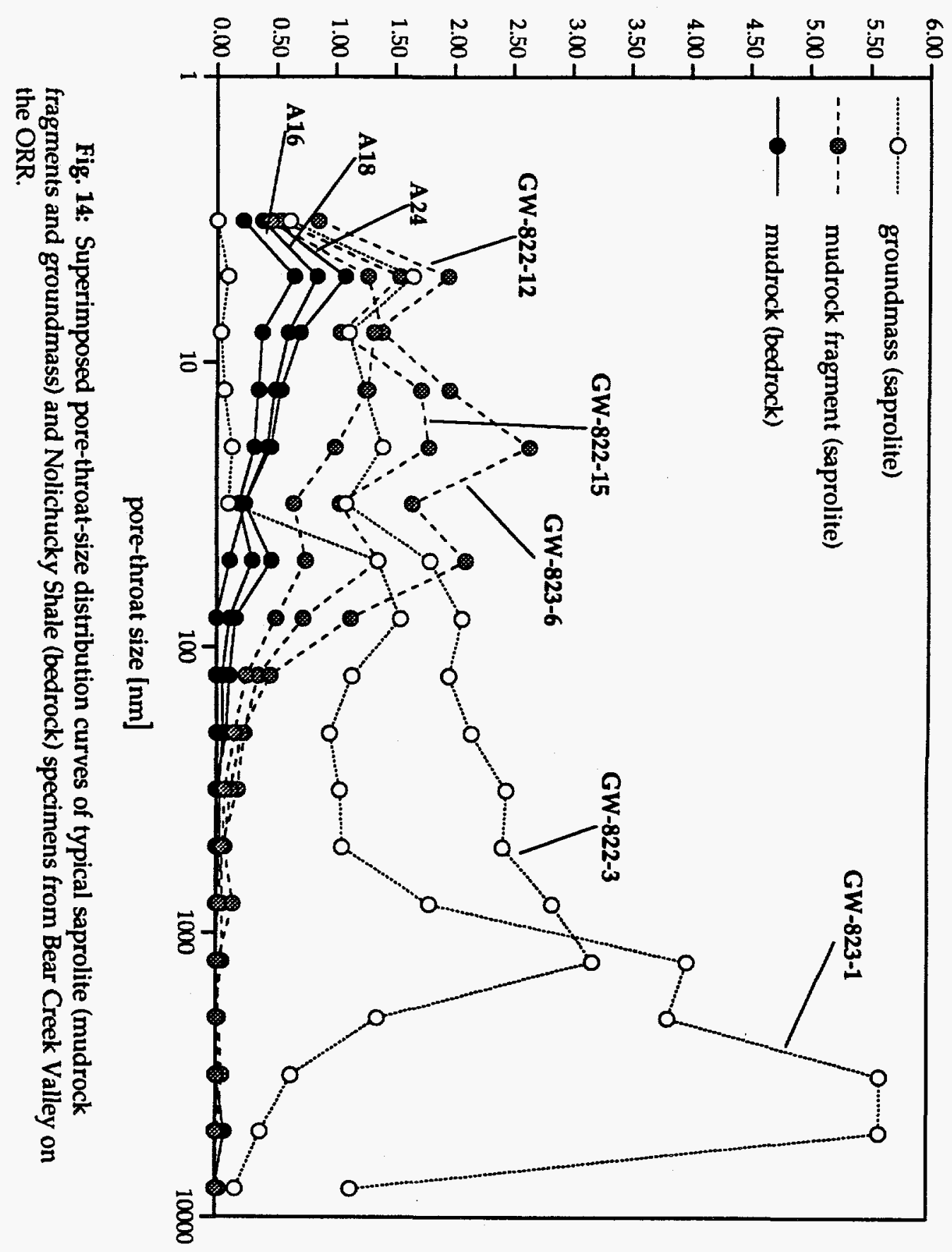

partial effective porosity [\%] 
In marked contrast to mudrock specimens (bedrock and saprolite), saprolitegroundmass specimens display pore-throat-size distribution curves which are skewed toward the left. Furthermore, the majority of pores is accessed by pore throats $\geq 100 \mathrm{~nm}$ in size (Appendix IV), and the throat-size spectrum is shifted even further to the right and toward larger throat sizes (Figure 14).

The overall shift of the pore-throat-size distribution curves to the right and toward larger throat sizes from bedrock mudrock, to saprolite mudrock-fragments, to saprolite groundmass (Figure 14) again reflects the increasing degree of changes brought on by chemical weathering. It is conceivable that cement lining pores and pore throats, clogging pore throats, and filling pores was (partially) removed during weathering, resulting in both an increase in effective porosity and an increase in the sizes of pore throats. The dissolved mineral phase was most likely carbonate cement (Lietzke, 1992; S. Y. Lee, pers. comm.).

While this observation is valid for comparing the different specimen types (bedrock, saprolite mudrock-fragments, saprolite groundmass), there are exceptions to the trend of decreasing weathering effects with depth apparent within the separate saprolite specimen-groups. For saprolite mudrock-fragments, a decrease in weathering influence might be surmised from the pore-throat-size distribution curves with depth (Figure 7), except for the anomalous character of specimen GW-822-15. This, however, might simply indicate that weathering zones have rather irregular boundaries and do not necessarily conform to parallelism with the ground surface (Figure 15; compare to Figure 2; Lietzke et al., 1988, pp. 8 to 9; see also Lee et al., 1992). The same holds true for the group of saprolite-groundmass specimens retrieved closer to the ground surface (Figure 15).

Measured data on pore-throat sizes and their distribution may be useful in evaluating whether pore throats can act to exclude or retard certain contaminant species from accessing the interconnected saprolite-matrix pore space through diffusion. Compared to mudrock specimens from bedrock (Dorsch et al., 1996), size exclusion of contaminant species appears to be of lesser significance because of the overall shift of the pore-throat size spectrum toward larger throat sizes for saprolite specimens (Figure 15). Nevertheless, small pore throats are still present within the saprolite matrix with the potential to influence contaminant transport by diffusion. 


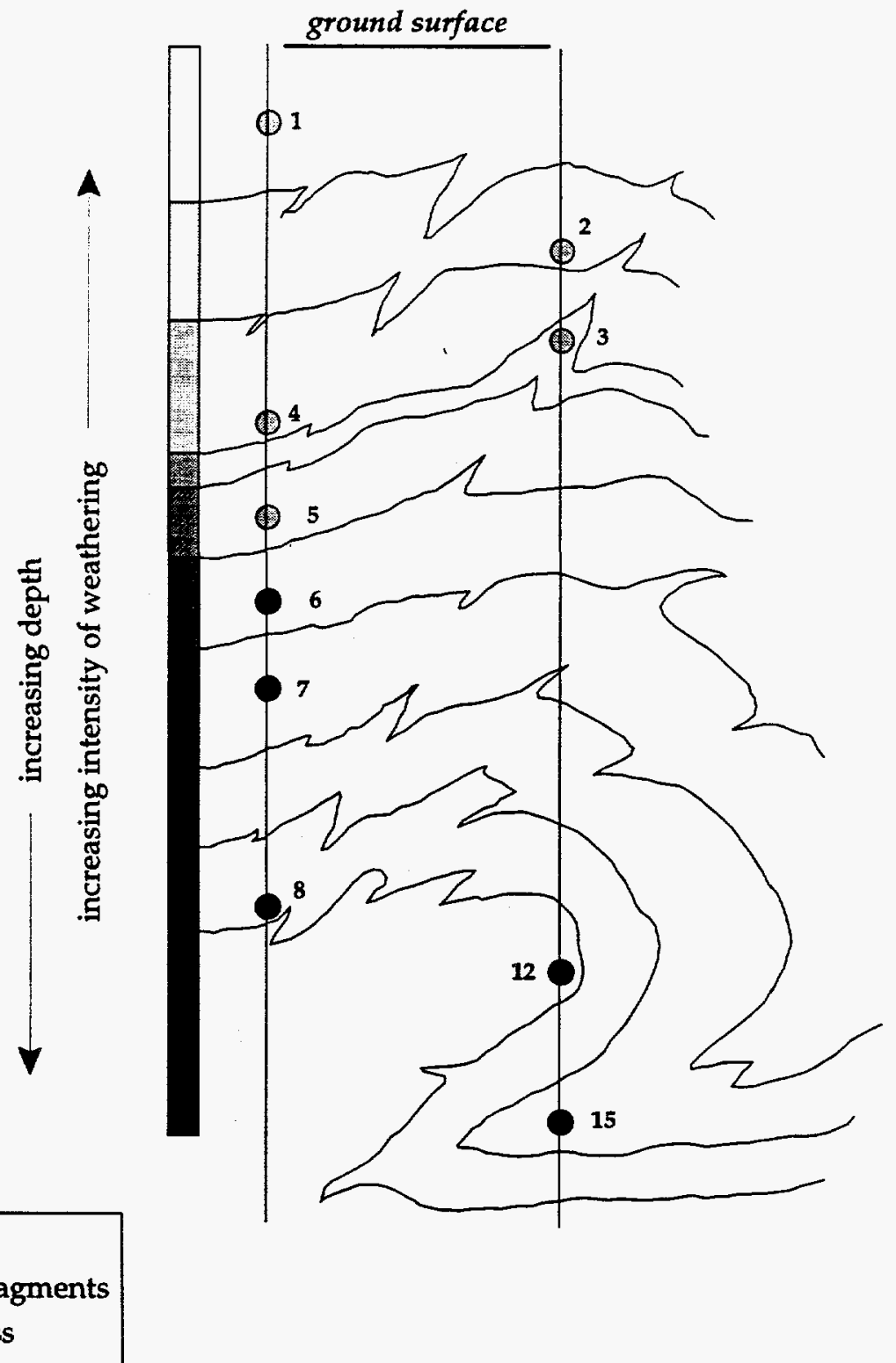

Fig. 15: Simplified illustration of the inferred boundaries of weathering zones within a saprolite mantle; based on spot measurements from two sections and interpretation of the resulting pore-throat-size distribution curves; note that boundaries of weathering zones are irregular in outline and are not parallel to the ground surface. 
Pore-throat size data from saprolite specimens can be used to aid in the interpretation of tracer behavior. McKay et al. (1995) performed microbial tracer experiments within the saprolite mantle (developed from Nolichucky Shale) of Bear Creek Valley on the ORR. Colloidal tracers for the experiments included bacteriophages PRD-1 (diameter of $62 \mathrm{~nm}$ ) and MS-2 (diameter $26 \mathrm{~nm}$ ), INA (a dead bacteria strain with an average diameter of $1000 \mathrm{~nm}$ ), and also fluorescent polymer microspheres (diameter of $100 \mathrm{~nm}$ ). The faster migration of the colloid-sized tracers, when compared to non-reactive solute tracers ( $\mathrm{He}, \mathrm{Ne}$; Sanford and Solomon, 1995), is attributed to diffusion of the solute tracers into the saprolite-matrix pore space but not of the larger sized colloidal tracers (McKay et al., 1995). McKay et al. (1995) interpret the large loss of colloids with distance from the injection well to be the result of filtration and sorption. The fast transport of colloid-sized tracers is accomplished within the interconnected fracture network of the saprolite mantle. The effective porosity provided by this fracture network was not determined but is believed to be relatively small, compared to the effective porosity of the saprolite matrix (Sanford, pers. comm.).

Figure 16 shows the pore-throat size distributions of the analyzed saprolitegroundmass specimens (see Appendix III). Groundmass is volumetrically the by far dominant part of the saprolite matrix. Superimposed on the curves are the sizes of colloidal-sized tracers. It is apparent that the pore-throat sizes are large and abundant enough to allow access of colloidal tracers into the saprolite-matrix pore space. Matrix diffusion is absent or minimal for colloidal tracers not because of size exclusion (especially for PRD-1 and MS-2), but probably because of relatively small diffusion coefficients. The reduction in concentration of colloidal tracers might be explained by infiltration of colloidal tracers into the saprolite-matrix pore space through active flow, either from the injection borehole into the wall of the borehole or from fractures into fracture walls. The smaller sized colloidal tracers (PRD-1 and MS-2) have more of the pore space available for infiltration (Figure 16) and will show a more severe reduction in concentration, as reported by McKay et al. (1995).

Fig. 16: Pore-throat-size distribution curves of saprolite groundmass specimens with superimposed sizes of colloidal tracers. The tracers (and their diameter) are as follows: 1 - MS-2 (26 nm), 2 - PRD-1 (62 nm), 3-polymer microspheres $(100 \mathrm{~nm}), 4$ - INA (average of $1000 \mathrm{~nm}$ ). For deeper intervals of the saprolite mantle, saprolite-groundmass specimen GW-823-5 probably provides the best approximation of throat sizes and their distribution. All documented pore-throat sizes fall within the micropore category for soils, as proposed by Luxmoore (1981). 


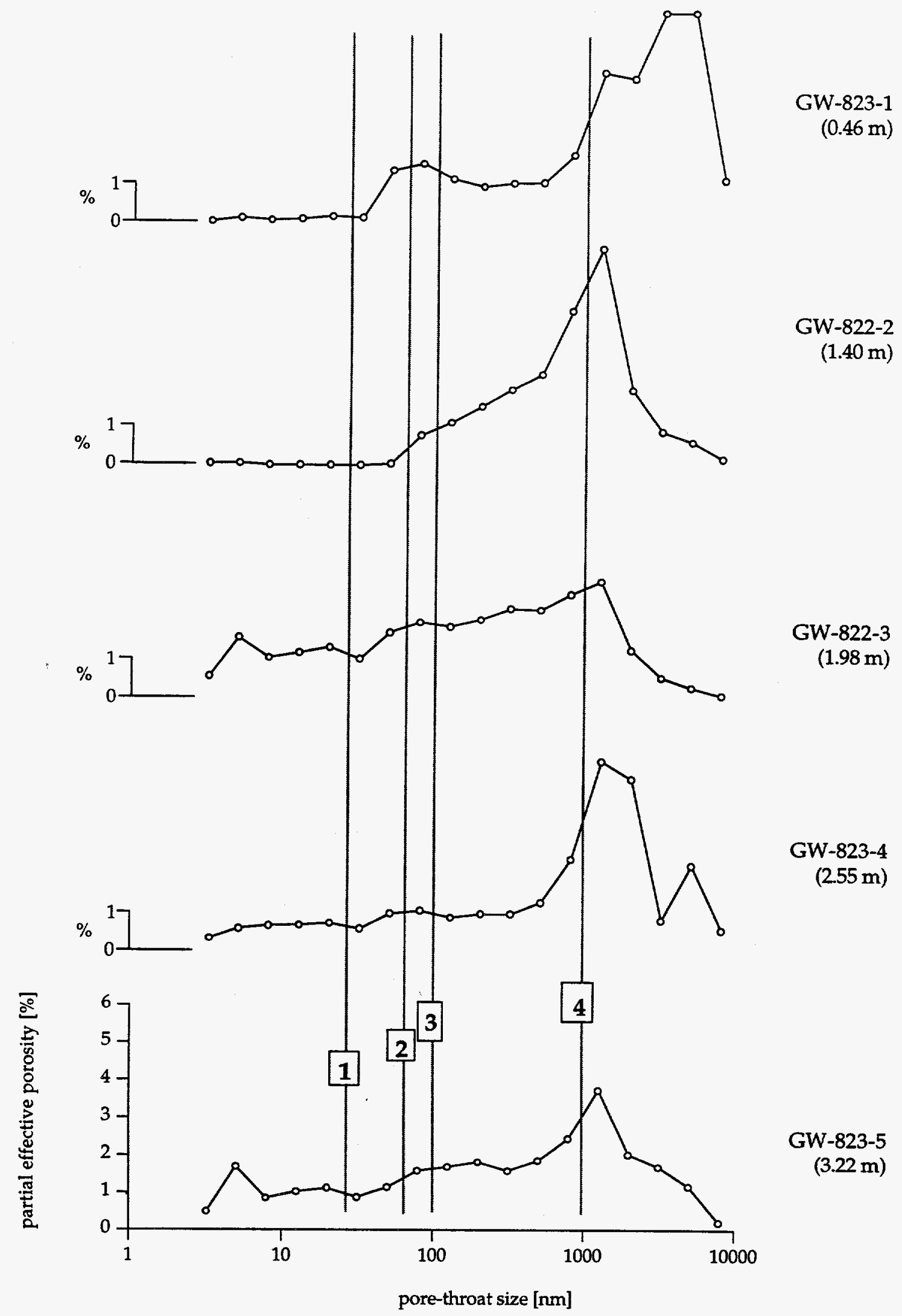




\section{Effective Porosity Data}

Comparison of Effective Porosities. Effective porosity values of saprolite specimens based on helium porosimetry are higher than effective porosity values based on mercury porosimetry (Table 2; Figure 17). This observation is in accordance with earlier studies on bedrock mudrock from different sedimentary basins (Issler and Katsube, 1994; Dorsch et al., 1996). The lone exception is the $\mathrm{Hg}-2$ data for saprolite-groundmass specimen GW-823-5 (Table 2; Figure 17).

A characteristic of all pore-throat-size distribution curves of analyzed saprolite specimens (except GW-823-1) is their abrupt termination at a pore-throat size of about $3 \mathrm{~nm}$ (Appendix IV). This corresponds to the analytical limit of commonly available mercury porosimeters, which cannot produce intrusion pressures high enough to force mercury into pores accessed by pore throats $\leq 3 \mathrm{~nm}$. The discrepancy between helium effective porosities and mercury effective porosities most likely reflects that the analyzed specimens possess pore space sheltered by pore throats $\leq 3 \mathrm{~nm}$ in size, precluding characterization by mercury but still allowing access by helium (Katsube, 1992; Issler and Katsube, 1994). This is in accordance with observations and interpretations on mudrock specimens from the Conasauga Group (bedrock) on the ORR (Dorsch et al., 1996). Based on this interpretation, the helium effective porosity data should be considered as a true reflection of the (maximum) effective porosity of the analyzed saprolite specimens.

Saprolite-groundmass data show also a truncation at about $8000 \mathrm{~nm}$ in the porethroat-size distribution curves (based on $\mathrm{Hg} 1$-data; Appendix IV). This might provide the opportunity for pore space sheltered by pore throats larger than about $8000 \mathrm{~nm}$ in size (not reported in the mercury data) which might add to the difference between helium and mercury effective porosities.

The large differences in helium and mercury effective porosities for saprolitegroundmass specimens GW-822-2 and GW-823-1 deserve special consideration. Porethroat-size distribution curves (Appendix IV) show zero or very low values for porethroat sizes from about 30 to about $5 \mathrm{~nm}$ for GW-822-2 (and less pronounced for GW823-1). Then it appears that pore-throat sizes smaller than about $5 \mathrm{~nm}$ again are present. This observation might reflect the possibility of a secondary creation of pore throats $\leq 5 \mathrm{~nm}$ in size through progressive chemical weathering. The increase in the difference between helium and mercury effective porosities in the most weathered zones might be explained by these added pore throats $\leq 5 \mathrm{~nm}$ (and especially $\leq 3 \mathrm{~nm}$ ) in size and their difference in accessibility to mercury and helium. 


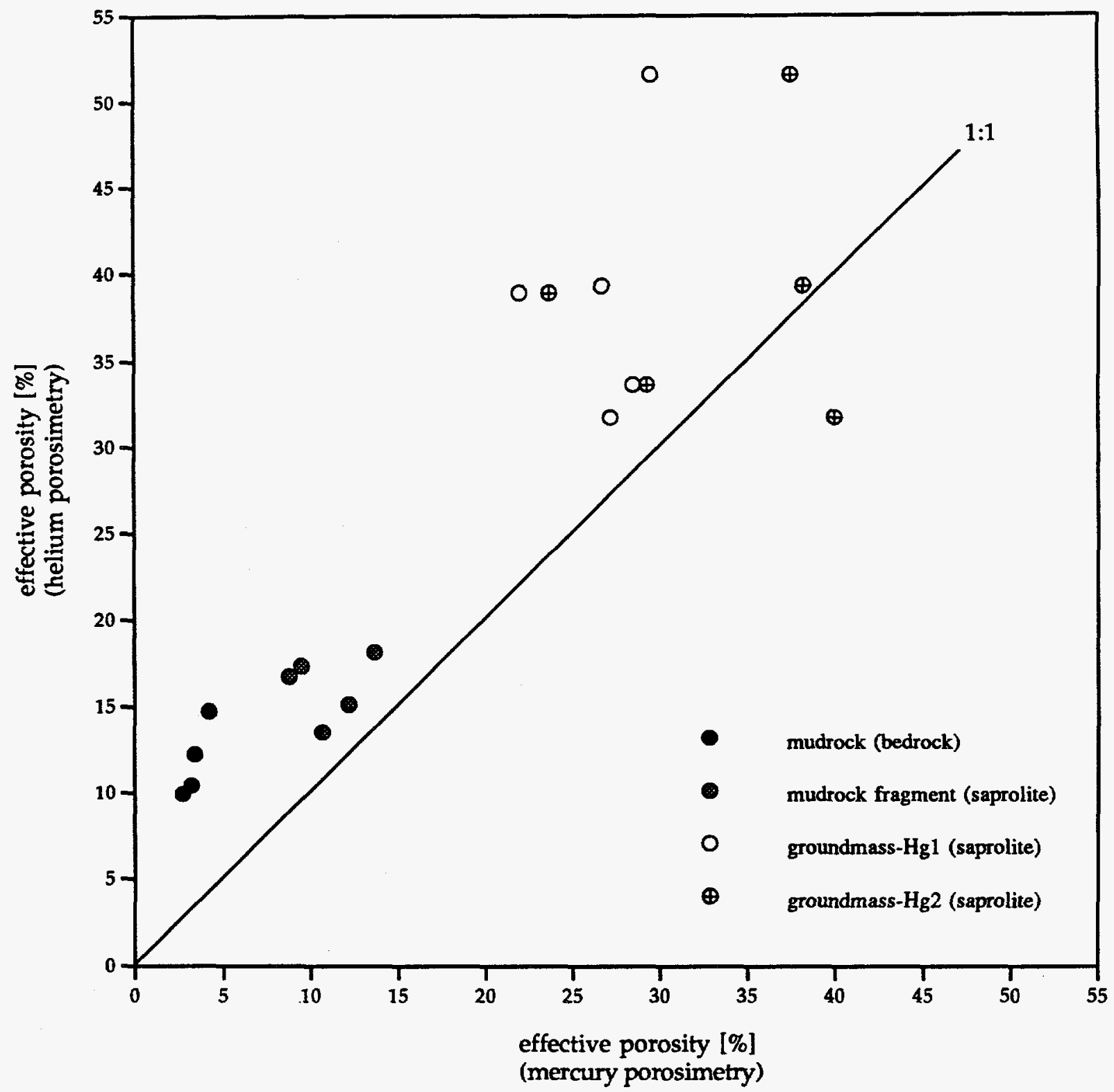

Fig. 17: Diagram plotting effective porosity based on mercury porosimetry against effective porosity based on helium porosimetry. Specimens are from Nolichucky Shale (bedrock) and from saprolite (mudrock fragments and groundmass), Bear Creek Valley on the ORR. Hg1-data are plotted throughout, and in addition $\mathrm{Hg} 2$-data for saprolite-groundmass specimens. Bedrock specimens with anomalously low effective porosity values based on helium porosimetry (see Dorsch et al., 1996) were disregarded. 
A remaining problem is saprolite-groundmass specimen GW-823-5 whose $\mathrm{Hg} 2-$ effective porosity exceeds helium effective porosity (Table 2). Reexamination of partial porosity data above pore-throat size $10000 \mathrm{~nm}$ showed a large amount of mercury intrusion at a size of $13000 \mathrm{~nm}$. This most likely reflects a microcrack of diameter 13000 $\mathrm{nm}$, which was not present in the groundmass specimen from the same sampling interval analyzed with helium porosimetry. (It is important to reiterate, that specimens with visible cracks were not used in analyses.) Specimen GW-823-5 was the only example showing this effective porosity signature. This can be interpreted to indicate that the other groundmass specimens were probably devoid of microcracks of a size $>8000 \mathrm{~nm}$. The occurrence of the microcrack might reflect heterogeneity on that scale within the sampling interval or might indicate an origin during the drying process for this single specimen.

The scatter for saprolite mudrock-fragments is small for helium and mercury effective porosities, whereas for saprolite-groundmass specimens the scatter is larger. This corresponds to observations on specimen density data and is interpreted to indicate the increased effect of weathering on saprolite-groundmass specimens.

Comparison to Bedrock. Mudrock specimens from the Nolichucky Shale (bedrock) show a mean effective porosity of $11.8( \pm 2.2) \%$ based on helium porosimetry with a minimum and maximum value of $9.9 \%$ and $14.7 \%$ (Appendices II, VI) (note: only reliable helium-porosimetry data were used, $n=4$; see discussion in Dorsch et al., 1996). Mercury-porosimetry data, in contrast, are much lower with a mean of 3.9 $( \pm 0.7) \%$ and a range from $2.7 \%$ to $5.1 \%$ (Appendices II, VI).

Helium-porosimetry data for saprolite mudrock-fragments are slightly higher than for bedrock mudrock, with their scatter being virtually identical (Figure 18). There is a distinct increase in value and scatter, however, for saprolite-groundmass specimens. Mercury-porosimetry data separate into distinct groups, with a step-wise increase in effective porosity from bedrock mudrock, through saprolite mudrock-fragments, to saprolite-groundmass specimens (Figure 18).

The increase in effective porosity and in scatter from bedrock mudrock to saprolite groundmass is again interpreted to reflect the increasing degree of changes associated with weathering. Dissolution of pore-and pore-throat-lining cement (predominantly carbonate) during chemical weathering enlarged pores and pore throats and can explain the increase in effective porosity from bedrock to saprolite mudrock fragments. Even more intense weathering and further dissolution of cement and of grain material, together with mechanical loosening of the grain fabric, may have caused the 

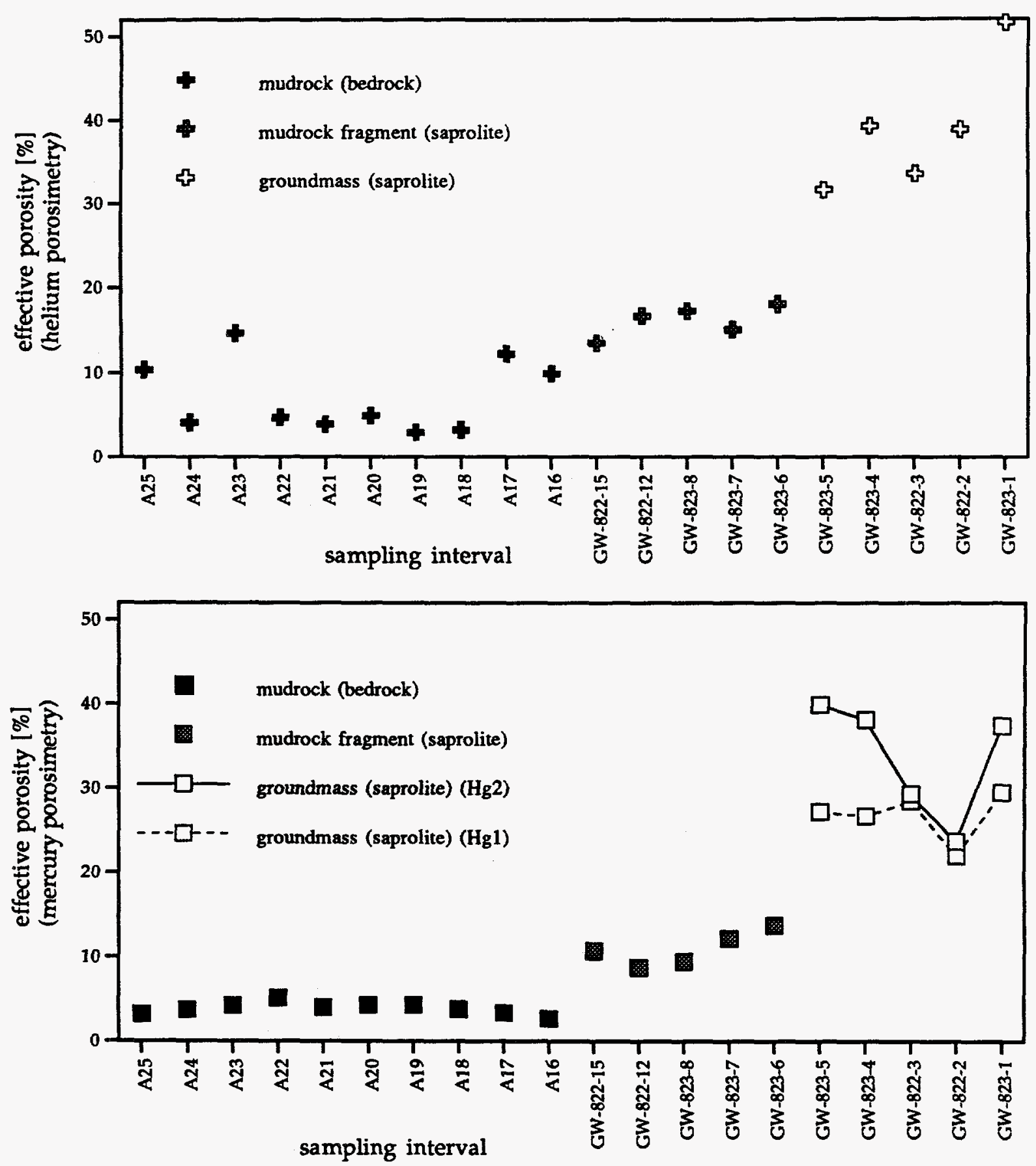

Fig. 18: Comparison of helium-porosimetry (upper graph) and mercury-porosimetry (lower graph) effective porosity data obtained from Nolichucky Shale (bedrock) and saprolite (mudrock fragments and groundmass), Bear Creek Valley on the ORR. 
drastic increase in effective porosity and scatter for saprolite groundmass.

The larger difference between effective porosity based on helium porosimetry and on mercury porosimetry for bedrock mudrock compared to saprolite mudrock-fragments might reflect that a larger part of the interconnected pore space in bedrock mudrock is sheltered by access pore-throats $\leq 3 \mathrm{~nm}$ in size (Dorsch et al., 1996). Weathering reduced the fraction of pore throats $\leq 3 \mathrm{~nm}$ for saprolite mudrock-fragments and mercury was able to characterize a larger fraction of the interconnected pore space. Helium, on the other hand, is not inhibited from accessing pore throats $\leq 3 \mathrm{~nm}$ in size (Katsube, 1992; Issler and Katsube, 1994).

Effective Porosities with Depth. A trend toward increasing effective porosity with decrease in depth is clearly discernible from the tightly clustered helium-porosimetry (only reliable data from bedrock) and mercury-porosimetry data when progressing from bedrock into the saprolite zone (Figure 19). This trend continues from saprolite mudrock-fragments to saprolite-groundmass specimens. The more drastic "jump" toward higher effective porosity values from saprolite mudrock-fragments to saprolite groundmass is caused by comparing mudrock fragments to groundmass. Saprolite groundmass occurs also at depths from which saprolite mudrock-fragments were collected (and vice versa), although in a smaller proportion. A comparison of groundmass (or mudrock fragments) throughout the saprolite mantle is expected to yield the same trend of increasing effective porosity with decreasing depth, albeit this trend is presumed to be smoother with a less severe "jump" in effective porosity values. The same statement applies for the drastic "jump" in bulk-density values within the saprolite mantle (Figure 13).

The effective porosity trend with depth reflects the decrease in weathering and associated changes with depth. The general depth profile is more complicated when the data within the two saprolite specimen groups (mudrock fragments and groundmass) are compared. Mercury-porosimetry data for saprolite mudrock-fragments conforms to the weathering picture developed from the analysis of pore-throat-size distribution curves (Figure 15), whereas helium-porosimetry data do not. Anomalously high heliumporosimetry data for GW-822-12 and GW-823-8, however, fall within the uncertainty of the analysis method. Helium-porosimetry data for saprolite groundmass correspond exactly to the weathering picture developed from the analysis of pore-throat-size distribution curves (Figure 15), as do most of the mercury-porosimetry data. Exceptions are specimens GW-823-5 (Hg2-data, explained above) and GW-822-2 (Hg1- and Hg2- 


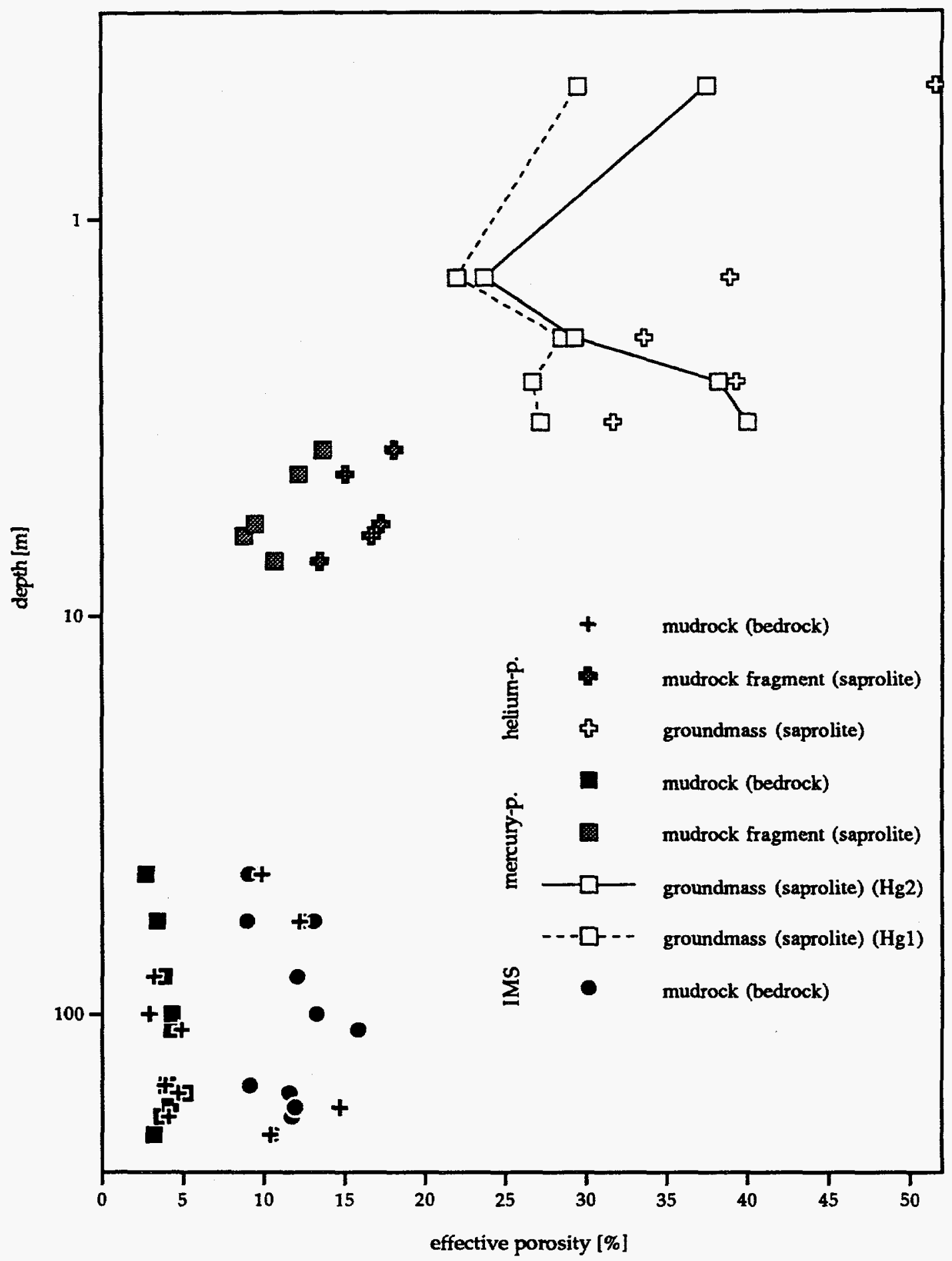

Fig. 19: Effective porosity with depth for Nolichucky Shale and saprolite specimens, Bear Creek Valley on the ORR. Maximum depth is $201.19 \mathrm{~m}$, minimum depth is $0.46 \mathrm{~m}$; depth is given as below ground surface. IMS refers to effective porosity obtained with the water-immersion method, mercury-p. and helium-p. refer to effective porosity obtained with mercury and helium porosimetry, respectively (note log-scale on depth axis). 
data are too low). The anomalously low mercury-porosimetry values (compared to the corresponding helium-porosimetry value) for specimen GW-822-2 probably emphasize newly created pore throats $\leq 5 \mathrm{~nm}$ in size caused by continued weathering (Appendices III, IV; see discussion above). Pore throats of this size shelter larger pores which cannot be accessed by mercury (lower detection limit of about $3 \mathrm{~nm}$ ) but by helium.

Overall, however, the effective porosity data within the different saprolitespecimen groups support the notion of irregularly-shaped boundaries of weathering zones within the saprolite mantle as developed previously from the analysis of porethroat-size distribution curves (Figure 15).

Calculated interval effective porosities show an exponential decrease in effective porosity with depth (Figure 20). This is interpreted to clearly show the increasing effect weathering had on the rock material with decreasing depth. Note the smooth transition toward lower effective porosity values with depth within the saprolite mantle. The prominent jump in petrophysical data within the saprolite mantle, observed in Figures 13 and 18 , is missing. A distinct jump toward lower effective porosity values (matrix), however, will occur at the saprolite-bedrock interface (compare to Lietzke et al., 1988), with average mudrock (bedrock) effective porosities (helium) of $11.8 \%$ (maximum 14.7\%) (Appendix 2; Figure 20) vs. $26.2 \%$ as the lowest saprolite-matrix effective porosity value.

The calculated saprolite matrix effective porosities conform to the picture of weathering zones and their boundaries (Figure 15), although the differences are more subtle (especially below $5 \mathrm{~m}$ depth).

The interval effective porosities are judged to be meaningful, especially for the modeling of contaminant behavior. They constitute quantitative data on saprolitematrix effective porosities over a larger saprolite volume, instead of effective porosities for small-volume specimens as used for petrophysical analysis. Furthermore, interval effective porosities incorporate the contribution of both types of saprolite materials, groundmass and "floating" mudrock fragments. The largest degree of uncertainty with these calculated effective porosity data is probably provided by the visual estimation of the proportion of groundmass vs. mudrock fragments for the chosen saprolite intervals. 


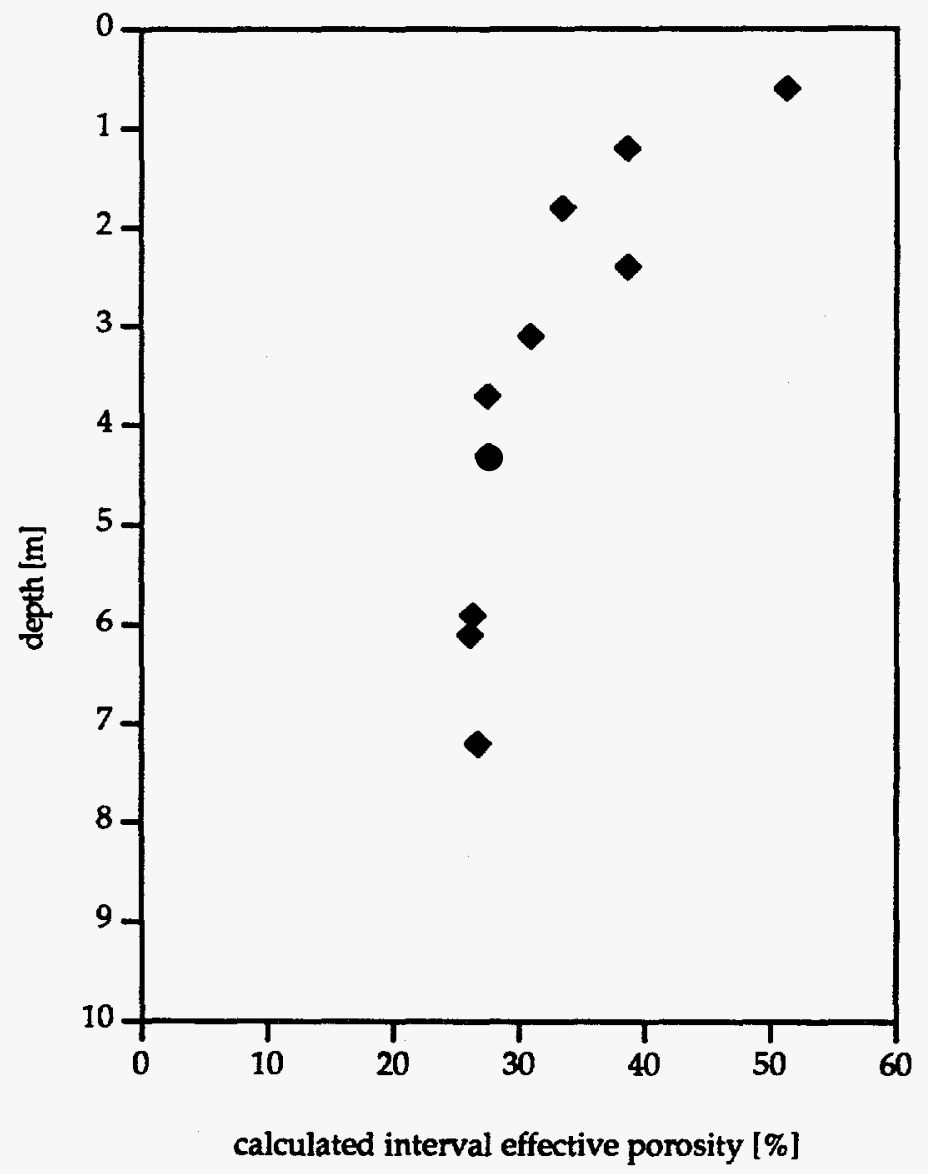

Fig. 20: Calculated interval effective porosity against depth. Porosities are based on helium porosimetry; for calculation and data see Appendix V. Depths are medians of intervals and are given as below ground surface. 


\section{CONCLUSIONS}

1. Specimens of mudrock saprolite from Bear Creek Valley, developed from Nolichucky Shale through weathering, were analyzed with helium and mercury porosimetry (Table 3). The undisturbed and fresh cores of the saprolite mantle yield two types of specimens: the volumetrically dominating, more extensively weathered saprolite groundmass and saprolite mudrock-fragments contained within the saprolite groundmass.

2. Saprolite mudrock-fragments possess average bulk-densities of $2.44 \mathrm{~g} \cdot \mathrm{cm}^{-3}$, and average grain-densities of $2.80 \mathrm{~g} \cdot \mathrm{cm}^{-3}$. Helium effective porosities are $16.1 \%$ and mercury effective porosities are $11.9 \%$ on average.

3. Saprolite-groundmass specimens possess average bulk-densities of 1.79 $\mathrm{g} \cdot \mathrm{cm}^{-3}$ and average grain-densities of $2.79 \mathrm{~g} \cdot \mathrm{cm}^{-3}$. Helium effective porosities are $39.0 \%$ and mercury effective porosities are $33.7 \%(\mathrm{Hg} 2)$ or $26.8 \%(\mathrm{Hg} 1)$ on average.

4. Effective porosity values from helium porosimetry are generally higher than values from mercury porosimetry for the same sampling interval. Mercury effective porosities are lower because of mechanical limitations of the analytical equipment. Helium effective porosities, therefore, are considered to provide the best estimates of the true (maximum) effective porosity of the analyzed specimens.

5. Petrophysical data display a consistent trend from bedrock mudrock, to saprolite mudrock-fragments, to saprolite groundmass: effective porosities (both helium and mercury) increase and specimen bulk-densities decrease, together with an increase in scatter of the data. This is interpreted to reflect the progressive effect of weathering on the rock material. Cement and some grain material was probably lost during weathering together with a gradual loosening of the grain fabric.

6. The pore-throat-size data for saprolite mudrock-fragments show normal distribution curves skewed toward the right with modes from 5 to $20 \mathrm{~nm}$. Most of the pores are accessed by pore throats $<100 \mathrm{~nm}$ in size. In marked contrast, pore-throatsize data for saprolite-groundmass specimens show normal distribution curves skewed toward the left with modes ranging from 1200 to $5000 \mathrm{~nm}$. Most of the pores are accessed by pore throats $>100 \mathrm{~nm}$ in size. The apparent shift of the throat-size spectrum toward larger sizes when progressing from bedrock mudrock, through saprolite mudrock-fragments, to saprolite groundmass reflects the progressive effect of weathering, with loss of pore-filling, pore-throat-lining and -plugging cement.

7. The pore-throat-size distribution curves also reveal that the boundaries of weathering zones are irregular in outline and do most likely not conform to the ground 
Table 3: Summary of petrophysical information on saprolite specimens (groundmass and mudrock fragments) from Bear Creek Valley on the ORR. The saprolite developed from Nolichucky Shale of the Conasauga Group through weathering. Petrophysical data for Nolichucky Shale bedrock from Bear Creek Valley are provided in Appendix VI (compare also to Dorsch et al., 1996). $\phi$ refers to effective porosity determined with helium porosimetry (He) or mercury porosimetry ( $\mathrm{Hg} 1, \mathrm{Hg} 2$, see text for discussion), whereas $\delta$ refers to specimen density $\left(\mathrm{He}=\right.$ grain density, $\mathrm{Hg}=$ bulk density); $\mathrm{d}_{H_{b}}$ refers to the geometric mean of the entire specimen pore-throat size distribution.

\begin{tabular}{cccccccccc} 
Sampling Interval & Corehole & $\begin{array}{c}\text { Depth } \\
{[\mathrm{m}]}\end{array}$ & $\begin{array}{r}\phi \mathrm{He} \\
{[\%]}\end{array}$ & $\begin{array}{r}\phi \mathrm{Hg} 1 \\
{[\%]}\end{array}$ & $\begin{array}{c}\phi \mathrm{Hg} 2 \\
{[\%]}\end{array}$ & $\begin{array}{c}\mathrm{d}_{\mathrm{Hz}} \\
{[\mathrm{nm}]}\end{array}$ & $\begin{array}{c}\delta_{\mathrm{He}} \\
{\left[\mathrm{g} \cdot \mathrm{cm}^{-3}\right]}\end{array}$ & $\begin{array}{c}\delta_{\mathrm{Hg}} \\
{\left[\mathrm{g} \cdot \mathrm{m}^{-3}\right]}\end{array}$ & $\begin{array}{c}\text { Specimen Type } \\
\text { (saprolite) }\end{array}$ \\
\hline GW-823-1 & GW-823 & 0.46 & 51.6 & 29.5 & 37.5 & 2201 & 2.76 & 1.48 & groundmass \\
GW-822-2 & GW-822 & 1.40 & 38.9 & 22.0 & 23.7 & 870 & 2.90 & 1.81 & groundmass \\
GW-822-3 & GW-822 & 1.98 & 33.6 & 28.5 & 29.3 & 182 & 2.87 & 1.92 & groundmass \\
GW-823-4 & GW-823 & 2.55 & 39.3 & 26.7 & 38.2 & 1823 & 2.70 & 1.64 & groundmass \\
GW-823-5 & GW-823 & 3.22 & 31.7 & 27.2 & 40.0 & 934 & 2.72 & 1.91 & groundmass \\
& & & & & & & & & \\
GW-823-6 & GW-823 & 3.79 & 18.1 & 13.7 & 14.0 & 27 & 2.78 & 2.36 & mudr. fragment \\
GW-823-7 & GW-823 & 4.37 & 15.1 & 12.2 & 12.8 & 24 & 2.78 & 2.39 & mudr. fragment \\
GW-823-8 & GW-823 & 5.84 & 17.3 & 9.5 & 10.1 & 25 & 2.80 & 2.40 & mudr. fragment \\
GW-822-12 & GW-822 & 6.25 & 16.7 & 8.8 & 9.2 & 18 & 2.81 & 2.50 & mudr. fragment \\
GW-822-15 & GW-822 & 7.24 & 13.5 & 10.7 & 11.2 & 28 & 2.81 & 2.53 & mudr. fragment
\end{tabular}


surface. The data indicate, furthermore, the probable creation of an additional population of pore throats $<5 \mathrm{~nm}$ in size for the most weathered specimens of saprolite groundmass, most likely caused by continued weathering.

8. Calculated interval effective porosities (based on petrophysical measurements and varied estimates) yield values between $51.3 \%$ and $26.2 \%$. The values decrease exponentially with depth and mirror the decreasing influence of weathering on the rock material with depth. The calculated interval effective porosities incorporate larger volumes of saprolite matrix and integrate both groundmass and mudrock-fragment effective porosities of the chosen saprolite intervals. These data appear of special significance for modeling and evaluating matrix diffusion as a transport process within the saprolite mantle. 


\section{References}

American Petroleum Institute (1960): Recommended Practices for Core-analysis Procedure. API Recommended Practice 40 (RP 40), 1st ed., American Petroleum Institute, Washington, D.C., 55 p.

Blatt, H., Middleton, G. V., and Murray, R. C. (1980): Origin of Sedimentary Rocks. PrenticeHall, Englewood Cliffs, NJ, 782 p.

Dorsch, J. (1995): Determination of effective porosity of mudrocks - A feasibility study. ORNL/GWPO-019, $60 \mathrm{p}$.

Dorsch, J., Katsube, T. J., Sanford, W. E., Dugan, B. E., and Tourkow, L. (1996): Effective porosity and pore-throat sizes of Conasauga Group Mudrock: Application, Test and Evaluation of Petrophysical Techniques. ORNL/GWPO-021.

Dreier, R. B., Solomon, D. K., and Beaudoin, C. M. (1987): Fracture characterization in the unsaturated zone of a shallow land burial facility. In: Flow and Transport through Fractured Rock. American Geophysical Union Monograph 40, p. 51-59.

Dreier, R. B., Hatcher, R. D., Jr., Lietzke, D. A. (1992): 3.3 Conasauga Group. In: R. D. Hatcher, Jr., P. J. Lemiszki, R. B. Dreier, R. H. Ketelle, R. R. Lee, D. A. Lietzke, W. M. McMaster, J. L. Foreman, and S. Y. Lee: Status Report on the Geology of the Oak Ridge Reservation. ORNL/TM-12074, p. 18-41.

Fairbridge, R. W. (1968): Regolith and saprolite. In: R. W. Fairbridge, ed., The Encyclopedia of Geomorphology, p. 933-936.

Germain, D., and Frind, E. O. (1989): Modelling of contaminant migration in fracture networks: Effects of matrix diffusion. Proceedings International Symposium on Contaminant Transport in Ground water, Stuttgart, Germany (April 1989), p.

Gwo, J. P., Jardine, P. M., Wilson, G. V., and Yeh, G. T. (1996): Using a multiregion model to study the effects of advective and diffusive mass transfer on local physical nonequilibrium and solute mobility in structured soil. Water Resources Research, v. 32, p. 561-570.

Hasson, K. O., and Haase, C. S. (1988): Lithofacies and paleogeography of the Conasauga Group (Middle and Late Cambrian) in the Valley and Ridge Province of East Tennessee. Geological Society of America Bulletin, v. 100, p. 234-246.

Hatcher, R. D., Jr., Lemiszki, P. J., Dreier, R. B., Ketelle, R. H., Lee, R. R., Lietzke, D. A., McMaster, W. M., Foreman, J. L., and Lee, S. Y. (1992): Status Report on the Geology of the Oak Ridge Reservation. ORNL/TM-12074, 247 p.

Issler, D. R., and Katsube, T. J. (1994): Effective porosity of shale samples from the BeaufortMackenzie Basin, northern Canada. In: Current Research, Part B. Geological Survey of Canada, p. 19-26.

Katsube, T. J. (1992): Statistical analysis of pore-size distribution data of tight shales from the Scotian Shelf. In: Current Research, Part E. Geological Survey of Canada, Paper 911E, p. 365-372.

Katsube, T. J., and Best, M. E. (1992): Pore structure of shales from the Beaufort-Mackenzie Basin, Northwest Territories. In: Current Research, Part D. Geological Survey of Canada, Paper 92-1E, p. 157-162. 
Katsube, T. J., and Issler, D. R. (1993): Pore-size distributions of shales from the BeaufortMackenzie Basin, northern Canada. In: Current Research, Part E. Geological Survey of Canada, Paper-1E, p. 123-132.

Katsube, T. J., and Scromeda, N. (1991): Effective porosity measuring procedure for low porosity rocks. In: Current Research, Part E. Geological Survey of Canada, Paper 91-1E, p. 291297.

Katsube, T. J., and Williamson, M. A. (1994): Shale petrophysics and basin charge modeling. In: Current Research, Part D. Geological Survey of Canada, Paper 91-1E, p. 291-297.

Katsube, T. J., Scromeda, N., and Williamson, M. (1992): Effective porosity from tight shales from the Venture gas field, offshore Nova Scotia. In: Current Research, Part $D$. Geological Survey of Canada, Paper 92-1D, p. 111-119.

Kopaska-Merkel, D. C. (1988): New applications in the study of porous media: Determination of pore-system characteristics on small fragments (part I). Northeastern Environmental Science, v. 7, p. 127-142.

Kopaska-Merkel, D. C. (1991): Analytical Procedure and Experimental Design for Geological Analysis of Reservoir Heterogeneity using Mercury Porosimetry. Alabama Geological Survey Circular 153, $29 \mathrm{p}$.

Lee, R. R., Ketelle, R. H., Bownds, J. M., and Rizk, T. A. (1992): Aquifer analysis and modeling in a fractured heterogeneous medium. Ground Water, v. 30, p. 589-597.

Lemiszki, P. J., and Hatcher, R. D., Jr. (1992): 5. Structure of the Oak Ridge Reservation. In: R. D. Hatcher, Jr., P. J. Lemiszki, R. B. Dreier, R. H. Ketelle, R. R. Lee, D. A. Lietzke, W. M. McMaster, J. L. Foreman, and S. Y. Lee: Status Report on the Geology of the Oak Ridge Reservation. ORNL/TM-12074, p. 109-178

Lietzke, D. A. (1992): 4. Oak Ridge Reservation soil survey. In: R. D. Hatcher, Jr., P. J. Lemiszki, R. B. Dreier, R. H. Ketelle, R. R. Lee, D. A. Lietzke, W. M. McMaster, J. L. Foreman, and S. Y. Lee: Status Report on the Geology of the Oak Ridge Reservation. ORNL/TM-12074, p. 69-107.

Lietzke, D. A., Lee, S. Y., and Lambert, R. E. (1988): Soils, Surficial Geology, and Geomorphology of the Bear Creek Valley Low-Level Waste Disposal Development and Demonstration Program Site. ORNL/TM-10573, 151 p.

Loman, J. M., Katsube, T. J., Correia, J. M., and Williamson, M. A. (1993): Effect of compaction on porosity and formation factor for tight shales from the Scotian Shelf, offshore Nova Scotia. In: Current Research, Part E. Geological Survey of Canada, Paper 93-1E, p. 331335.

Luffel, D. L., and Howard, W. E. (1988): Reliability of laboratory measurement of porosity in tight gas sands. SPE Formation Evaluation, December, p. 705-710.

Luxmoore, R. J. (1981): Micro-, meso-, and macroporosity of soil. Soil Sci. Soc. Am. J., v. 45, p. $671-672$.

McKay, L. D., Gillham, R. W., and Cherry, J. A. (1993): Field experiments in a fractured clay till 2. Solute and colloid transport. Water Resources Research, v. 29, p. 3879-3890.

McKay, L. D., Sanford, W. E., Strong-Gunderson, J., and De Enriquez, V. (1995): Microbial tracer experiments in a fractured weathered shale near Oak Ridge, Tennessee. Proceedings, Intern. Assoc. Hydrogeologists, Solutions ' 95 Conference. Edmonton, Alberta, Canada. 
Moline, G. R., and Schreiber, M. E. (1995): FY94 Site Characterization and Multilevel Well Installation at a West Bear Creek Valley Research Site on the Oak Ridge Reservation. ORNL/TM-13029.

Neretnieks, I. (1980): Diffusion in the rock matrix: An important factor in radionuclide retardation? Joumal of Geophysical Research, v. 85, p. 4379-4397.

Rootare, H. M. (1970): A review of mercury porosimetry. Perspectives of Powder Metallurgy, v. 5, p. 225-252.

Sanford, W. E., and Solomon, D. K. (1995): Noble gas solute tracer experiment in a fractured, weathered shale near Oak Ridge, Tennessee. Proceedings, Intern. Assoc. Hydrogeologists, Solutions ' 95 Conference. Edmonton, Alberta, Canada.

Sanford, W. E., Jardine, P. M., and Solomon, D. K. (1994): Examining matrix diffusion in fractured shales with noble gases. Geological Society of America Abstracts with Programs, v. 26, p. A362.

Schreiber, M. E. (1995): Spatial Variability in Groundwater Chemistry in Fractured Rock: Nolichucky Shale, Oak Ridge, TN. Unpublished M. Sc. thesis, University of Wisconsin, Madison, 248 p.

Scromeda, N., and Katsube, T. J. (1993): Effect of vacuum-drying and temperature on effective porosity determination for tight rocks. In: Current Research, Part E. Geological Survey of Canada, Paper-1E, p. 313-319.

Shevenell, L. M., Moore, G. K., and Dreier, R. B. (1994): Contaminant spread and flushing in fractured rocks near Oak Ridge, Tennessee. Ground Water Monitoring \& Remediation, v. 14 , p. 120-129.

Soeder, D. J. (1988): Porosity and permeability of eastern Devonian gas shales. SPE Formation Evaluation, v. 3, p. 116-138.

Solomon, D. K., Moore, G. K., Toran, L. E., Dreier, R. B., and McMaster, W. M. (1992): Status Report: A Hydrologic Framework for the Oak Ridge Reseroation. ORNL/TM-12026. Oak Ridge National Laboratory, Oak Ridge, Tenn., variously paginated.

Tang, D. H., Frind, E. O., and Sudicky, E. A. (1981): Contaminant transport in fractured porous media: Analytical solution for a single fracture. Water Resources Research, v. 17, p. 555-564.

Toran, L., Sjoreen, A., and Morris, M. (1995): Sensitivity analysis of solute transport in fractured porous media. Geophysical Research Letter, v. 22, p. 1433-1436.

Wardlaw, N. C. (1976): Pore geometry of carbonate rocks as revealed by pore casts and capillary pressure. American Association of Petroleum Geologists Bulletin, v. 60, p. 245-257.

Wardlaw, N. C., McKellar, M., and Yu, Li (1988): Pore and throat size distribution determined by mercury porosimetry and by direct observation. Carbonates and Evaporites, v. 3, p. 1-15.

Washburn, E. W. (1921): Note on a method of determining the distribution of pore sizes in a porous material. Proceedings of the National Academy of Sciences, v. 5, p. 115-116.

Wickliff, D. S., Solomon, D. K., and Farrow, N. D. (1991): Preliminary Investigation of Processes that affect Source Term Identification. ORNL/ER 59, Oak Ridge National Laboratory, Oak Ridge, Tenn., 31 p. 


\section{APPENDIX I: Sampling Intervals}

Summary information on sampling locations of specimens: designation of sampling intervals, cores, drill depths (below ground surface), and specimen type. 'Saprolite groundmass' and 'mudrock fragment' designate specimens from Nolichucky Shale saprolite, whereas 'mudrock (bedrock)' designates specimens from Nolichucky Shale bedrock within Bear Creek Valley.

\begin{tabular}{llll} 
Sampling Interval & Corehole & \multicolumn{1}{c}{ Drill Depth } & Specimen Type \\
\hline GW-822-2 & GW-822 & $4^{\prime} 7^{\prime \prime}(1.40 \mathrm{~m})$ & saprolite groundmas \\
GW-822-3 & GW-822 & $6^{\prime} 6^{\prime \prime}(1.98 \mathrm{~m})$ & saprolite groundmas \\
GW-823-1 & GW-823 & $1^{\prime} 6^{\prime \prime}(0.46 \mathrm{~m})$ & saprolite groundmas \\
GW-823-4 & GW-823 & $8^{\prime} 4^{\prime \prime}(2.55 \mathrm{~m})$ & saprolite groundmas \\
GW-823-5 & GW-823 & $1^{\prime} 7^{\prime \prime}(3.22 \mathrm{~m})$ & saprolite groundmas \\
& & & \\
GW-822-12 & GW-822 & $20^{\prime} 6^{\prime \prime}(6.25 \mathrm{~m})$ & mudrock fragment \\
GW-822-15 & GW-822 & $23^{\prime} 9^{\prime \prime}(7.24 \mathrm{~m})$ & mudrock fragment \\
GW-823-6 & GW-823 & $12^{\prime} 5^{\prime \prime}(3.79 \mathrm{~m})$ & mudrock fragment \\
GW-823-7 & GW-823 & $14^{\prime} 4^{\prime \prime}(4.37 \mathrm{~m})$ & mudrock fragment \\
GW-823-8 & GW-823 & $19^{\prime} 2^{\prime \prime}(5.84 \mathrm{~m})$ & mudrock fragment
\end{tabular}

$\begin{array}{llll}\text { A16 } & \text { GW-134 } & 1^{145^{\prime}} 10^{\prime \prime}(44.45 \mathrm{~m}) & \text { mudrock (bedrock)* } \\ \text { A17 } & \text { GW-134 } & 1^{\prime} 1^{\prime} 2^{\prime \prime}(58.27 \mathrm{~m}) & \text { mudrock (bedrock) } \\ \text { A18 } & \text { GW-134 } & 23^{\prime} 5^{\prime \prime}(80.29 \mathrm{~m}) & \text { mudrock (bedrock) } \\ \text { A19 } & \text { GW-134 } & 3^{\prime} 7^{\prime} 5^{\prime \prime}(99.80 \mathrm{~m}) & \text { mudrock (bedrock) } \\ \text { A20 } & \text { GW-134 } & 359^{\prime} 4^{\prime \prime}(109.53 \mathrm{~m}) & \text { mudrock (bedrock) } \\ \text { A21 } & \text { GW-134 } & 4^{\prime \prime} 7^{\prime} 4^{\prime \prime}(151.59 \mathrm{~m}) & \text { mudrock (bedrock) } \\ \text { A22 } & \text { GW-134 } & 519^{\prime} 3^{\prime \prime}(158.27 \mathrm{~m}) & \text { mudrock (bedrock) } \\ \text { A23 } & \text { GW-134 } & 563^{\prime} 10^{\prime \prime}(171.86 \mathrm{~m}) & \text { mudrock (bedrock) } \\ \text { A24 } & \text { GW-134 } & 617^{\prime} 3^{\prime \prime}(181.14 \mathrm{~m}) & \text { mudrock (bedrock) } \\ \text { A25 } & \text { GW-134 } & 660^{\prime} 1^{\prime \prime}(201.19 \mathrm{~m}) & \text { mudrock (bedrock) }\end{array}$

* indicates specimens analyzed for an earlier study on Conasauga Group mudrock (Dorsch et al., 1996). 


\section{APPENDIX II: Statistical Measures}

Some statistical measures calculated for specimens of Nolichucky Shale (bedrock) and saprolite (mudrock fragments and groundmass) from Bear Creek Valley on the ORR. Density measures are in $\mathrm{g} \cdot \mathrm{cm}^{-3}$ and porosity measures are in \%. Abbreviations: $x=$ arithmetic mean, $s x=$ standard deviation, $\mathbf{n}=$ is number of specimen analyses, $\min =$ minimum value, max $=$ maximum value. Data for bedrock specimens are from Dorsch et al. (1996). Note that helium-porosimetry measures for bedrock specimens lists only reliable values (see further detail in Dorsch et al., 1996). 


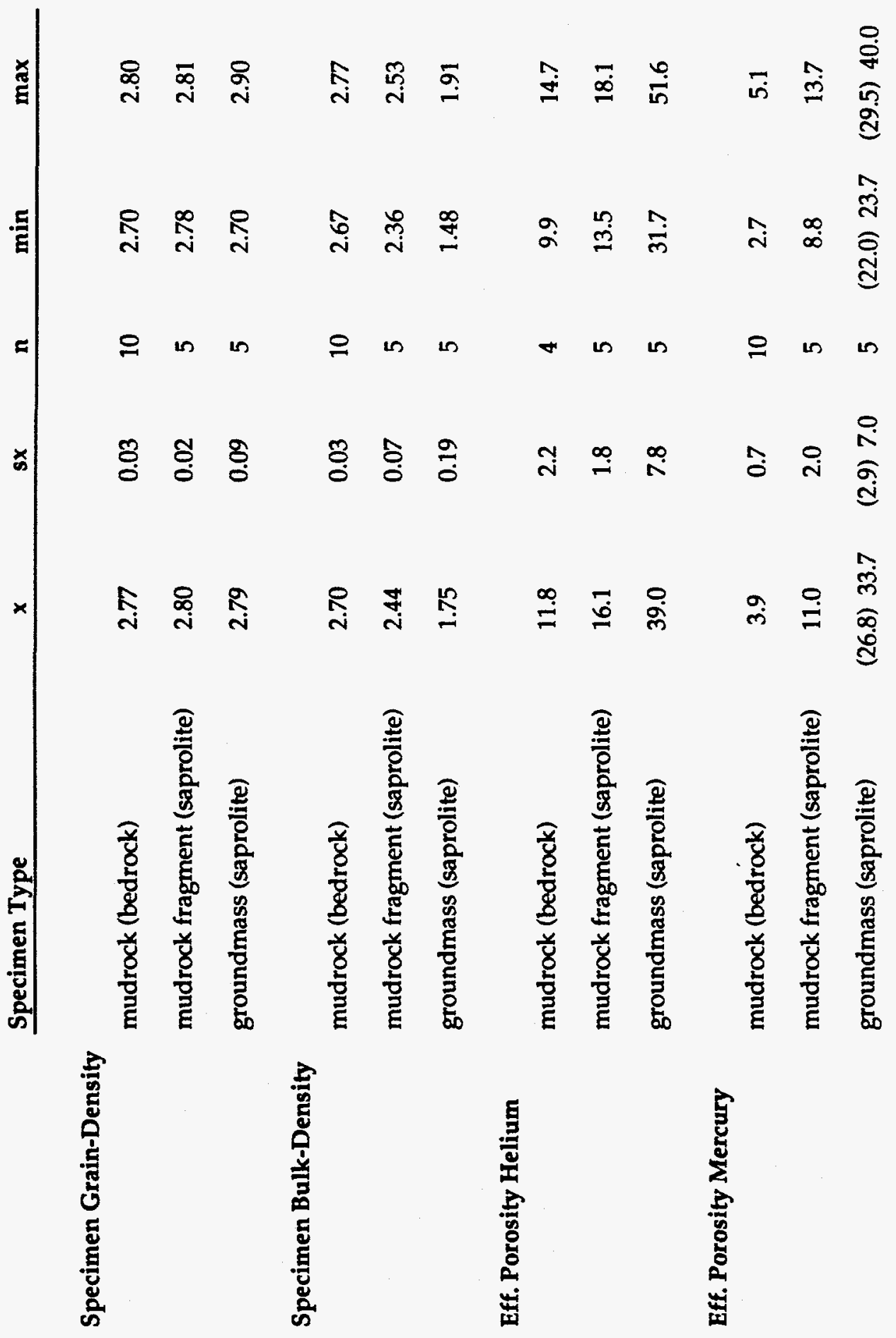




\section{APPENDIX III: Results - Pore-Throat Sizes}

Tabulation of pore-throat size data obtained with mercury porosimetry. Abbreviations are as follows: $d(\mathrm{~nm})$ refers to the geometric mean porethroat sizes for the different pore-throat-size ranges (expressed in nanometers), $\phi$ a refers to the partial porosity (expressed in percent), $\phi_{\mathrm{Hg} 1}$ refers to effective porosity measured by mercury porosimetry for pore-throat sizes $\leq 10 \mu \mathrm{m}$ (expressed in percent), $\phi \mathrm{Hg} 2$ refers to effective porosity measured by mercury porosimetry for pore-throat sizes $\leq 250 \mu \mathrm{m}$ (expressed in percent), and $\mathrm{dHg}$ refers to the geometric mean of the entire pore-throat-size distribution (expressed in nanometers) for the analyzed specimen. 
GW-822-12 GW-822-15 GW-823-6 GW-823-7 GW-823-8 GW-822-2 GW-822-3 GW-823-1 GW-823-4 GW-823-5

\begin{tabular}{|c|c|c|c|c|c|c|c|c|c|c|}
\hline$d(n m)$ & $\phi \mathrm{a}[\%]$ & $\phi a[\%]$ & $\phi a[\%]$ & $\phi \mathrm{a}[\%]$ & $\phi \mathbf{a}[\%]$ & $\phi \mathrm{a}[\%]$ & $\phi \mathbf{a}[\%]$ & $\phi \mathbf{a}[\%]$ & $\phi a[\%]$ & $\phi a[\%]$ \\
\hline 3.2 & 0.85 & 0.53 & 0.45 & 0.79 & 0.67 & 0.04 & 0.61 & 0.00 & 0.38 & 0.50 \\
\hline 5 & 1.95 & 1.54 & 1.27 & 1.77 & 1.99 & 0.05 & 1.65 & 0.09 & 0.64 & 1.70 \\
\hline 7.9 & 1.32 & 1.04 & 1.39 & 1.87 & 1.63 & 0.00 & 1.11 & 0.03 & 0.72 & 0.86 \\
\hline 12.6 & 1.27 & 1.72 & 1.96 & 2.08 & 1.46 & 0.00 & 1.25 & 0.06 & 0.74 & 1.03 \\
\hline 20 & 1.00 & 1.79 & 2.64 & 2.15 & 1.27 & 0.00 & 1.40 & 0.13 & 0.79 & 1.13 \\
\hline 31.6 & 0.65 & 1.04 & 1.65 & 0.86 & 0.60 & 0.00 & 1.09 & 0.10 & 0.65 & 0.88 \\
\hline 50.1 & 0.75 & 1.36 & 2.10 & 1.17 & 0.65 & 0.04 & 1.80 & 1.36 & 1.05 & 1.15 \\
\hline 79.4 & 0.50 & 0.73 & 1.13 & 0.55 & 0.53 & 0.80 & 2.07 & 1.55 & 1.13 & 1.59 \\
\hline 126 & 0.25 & 0.35 & 0.45 & 0.31 & 0.22 & 1.14 & 1.96 & 1.14 & 0.95 & 1.70 \\
\hline 200 & 0.15 & 0.23 & 0.21 & 0.17 & 0.14 & 1.57 & 2.15 & 0.95 & 1.05 & 1.83 \\
\hline 316 & 0.07 & 0.18 & 0.12 & 0.12 & 0.12 & 2.01 & 2.45 & 1.04 & 1.05 & 1.59 \\
\hline 501 & 0.05 & 0.05 & 0.07 & 0.07 & 0.02 & 2.42 & 2.42 & 1.06 & 1.36 & 1.87 \\
\hline 794 & 0.02 & 0.05 & 0.14 & 0.12 & 0.00 & 4.09 & 2.84 & 1.80 & 2.51 & 2.46 \\
\hline 1259 & 0.00 & 0.05 & 0.02 & 0.05 & 0.00 & 5.75 & 3.18 & 3.98 & 5.12 & 3.76 \\
\hline 1995 & 0.00 & 0.00 & 0.02 & 0.05 & 0.00 & 2.01 & 1.36 & 3.82 & 4.65 & 2.04 \\
\hline 3162 & 0.00 & 0.03 & 0.05 & 0.05 & 0.17 & 0.92 & 0.63 & 5.60 & 0.90 & 1.70 \\
\hline 5012 & 0.00 & 0.00 & 0.02 & 0.00 & 0.00 & 0.65 & 0.38 & 5.60 & 2.36 & 1.18 \\
\hline 7943 & 0.00 & 0.03 & 0.00 & 0.00 & 0.00 & 0.20 & 0.17 & 1.14 & 0.65 & 0.21 \\
\hline$\phi_{\mathrm{Hg} 1}[\%]$ & 8.8 & 10.7 & 13.7 & 12.2 & 9.5 & 22.0 & 28.5 & 29.5 & 26.7 & 27.2 \\
\hline$\phi_{\mathrm{H} 22}[\%]$ & 9.2 & 11.2 & 14.0 & 12.8 & 10.1 & 23.7 & 29.3 & 37.5 & 38.2 & 40.4 \\
\hline $\mathrm{d}_{\mathbf{H}}[\mathrm{nm}]$ & 18 & 28 & 27 & 24 & 25 & 870 & 182 & 2201 & 1823 & 934 \\
\hline
\end{tabular}




\section{APPENDIX IV: Pore-Throat-Size Distribution-Curves}

Pore-throat-size distribution curves for Nolichucky Shale saprolite specimens from Bear Creek Valley on the ORR analyzed with mercury porosimetry.
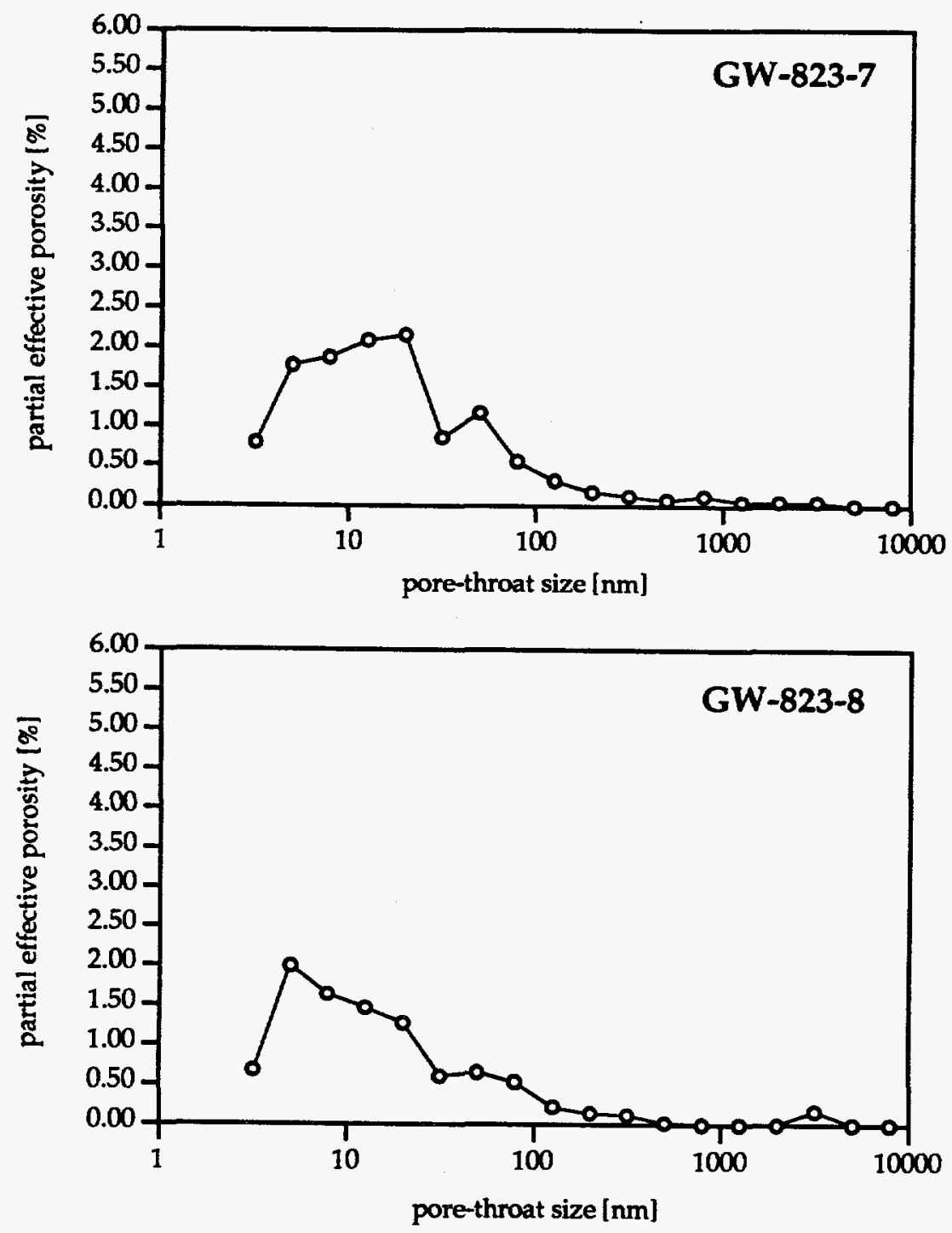

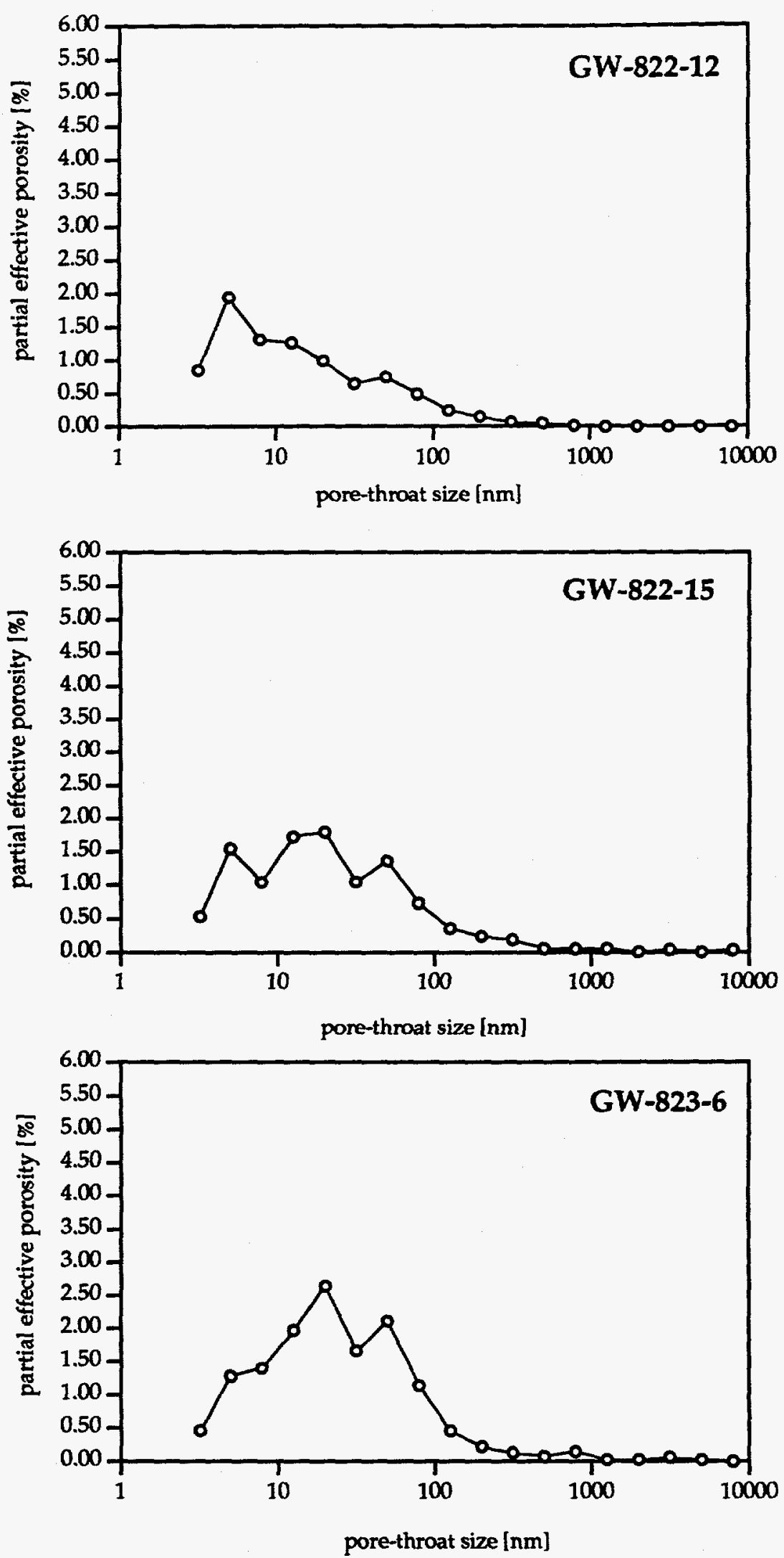

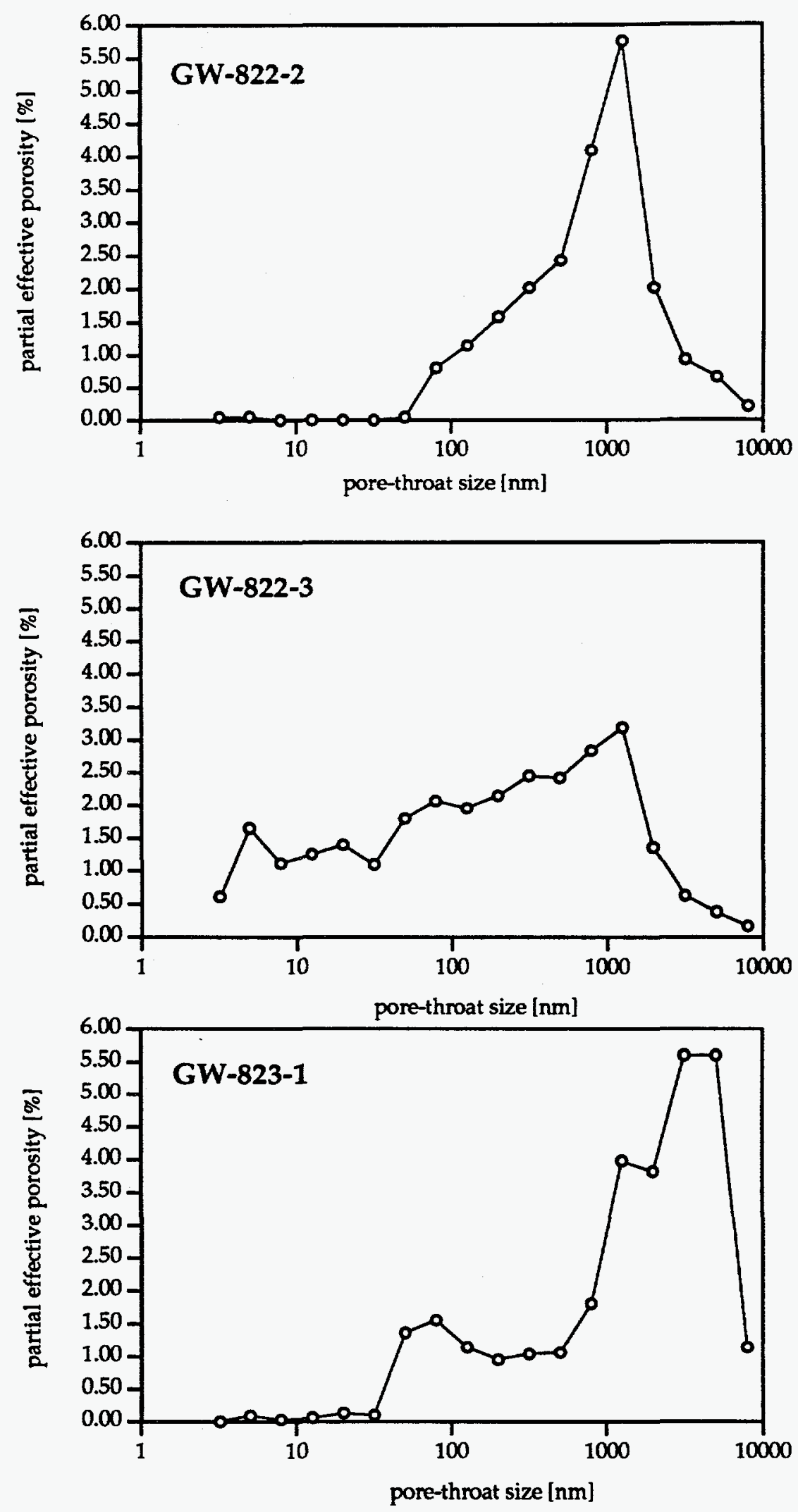

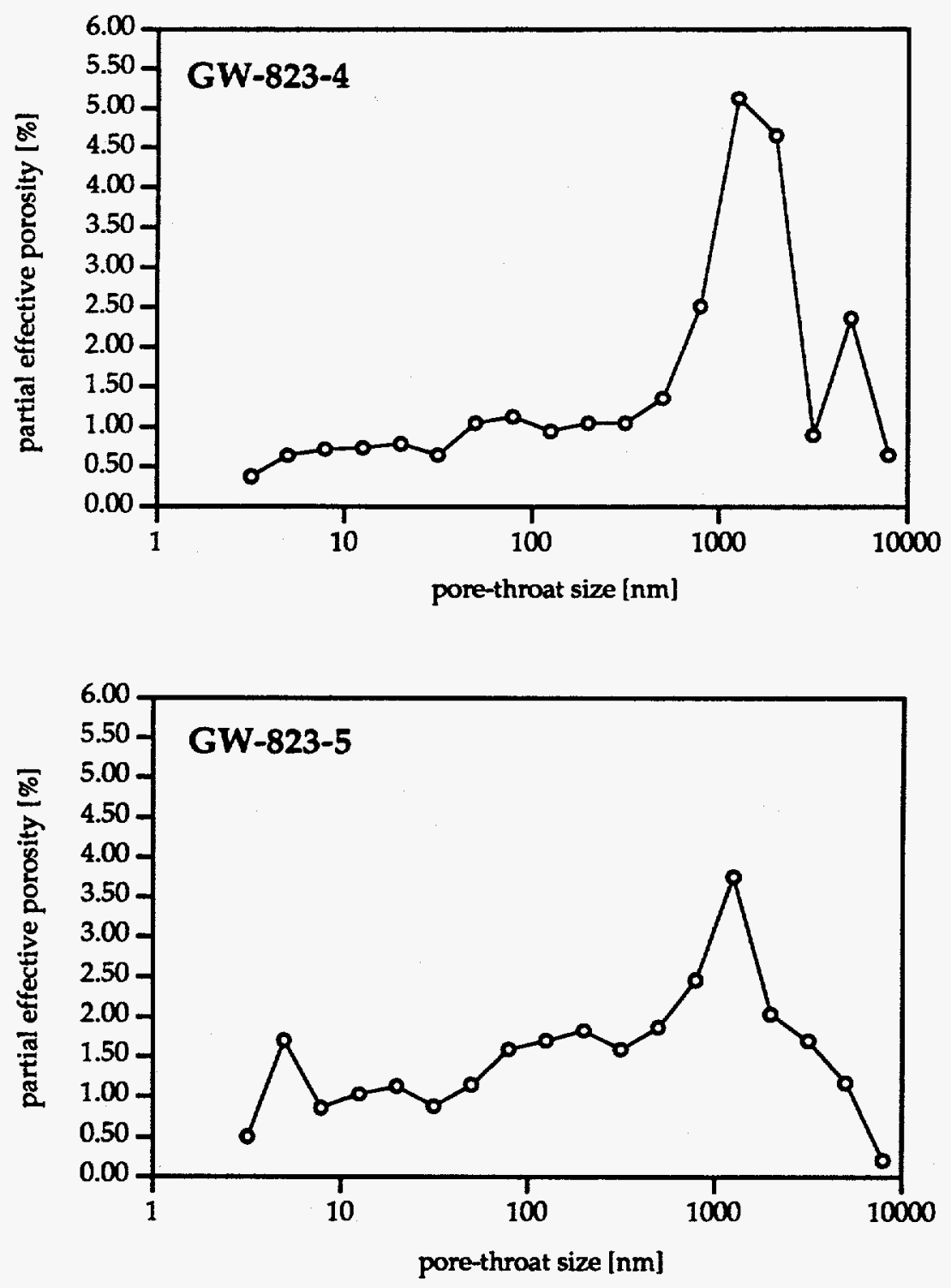


\section{APPENDIX V: Data for Calculation of Interval Effective Porosity}

Summary of data used for the calculation of interval effective porosity of saprolite developed from Nolichucky Shale, Bear Creek Valley on the ORR. Depth range is given as below ground surface. Effective porosity data were determined with helium porosimetry, judged to more likely provide accurate (maximum) effective porosity values. Assumed effective porosity values are to complement measured effective porosity values for the different sampling intervals. The assumed value for mudrock fragments is the highest effective porosity value from a mudrock fragment below interval 5 . It is judged as the most weathered petrophysically tested mudrock fragment and is interpreted to best approximate the effective porosity of mudrock fragments within intervals 1 to 5 . The assumed value for groundmass is the lowest effective porosity value from a groundmass specimen above interval 6 . It is judged as the least weathered petrophysically tested groundmass specimen and is interpreted to best approximate the effective porosity of saprolite groundmass within intervals 6 to 15. For intervals 1 through 5, the assumed value (for mudrock fragment) probably is a minimum value which makes the calculated interval effective porosities also minimum values (note, however, that these intervals are strongly dominated by groundmass, reducing severely the impact of mudrock fragment effective porosity). For intervals 6 through 15, the assumed value (for groundmass) probably is a maximum value which makes the calculated interval effective porosities also maximum values. The largest degree of uncertainty is provided by visually estimating the proportion of groundmass vs. mudrock fragments within the chosen saprolite intervals. Intervals 6 through 15 have a higher degree of uncertainty, with interval 15 providing the most difficulty for estimation. 


\begin{tabular}{|c|c|c|c|c|c|c|c|}
\hline \multirow[b]{2}{*}{ interval } & \multirow[b]{2}{*}{ corehole } & \multirow{2}{*}{$\begin{array}{c}\text { depth range } \\
\text { (below ground surf.) }\end{array}$} & \multicolumn{2}{|c|}{ proportion } & \multicolumn{2}{|c|}{ specimen eff. porosity [\%] } & \multirow{2}{*}{$\begin{array}{l}\text { calculated interval } \\
\text { eff. porosity [\%] }\end{array}$} \\
\hline & & & fragments & groundmass & fragments & groundmass & \\
\hline 1 & GW-823 & $0.3 \mathrm{~m}$ to $0.9 \mathrm{~m}$ & 0.01 & 0.99 & $18.1^{*}$ & 51.6 & 51.3 \\
\hline 2 & GW-822 & $0.9 \mathrm{~m}$ to $1.5 \mathrm{~m}$ & 0.01 & 0.99 & $18.1^{*}$ & 38.9 & 38.7 \\
\hline 3 & GW-822 & $1.5 \mathrm{~m}$ to $2.1 \mathrm{~m}$ & 0.01 & 0.99 & $18.1^{*}$ & 33.6 & 33.5 \\
\hline 4 & GW-823 & $2.1 \mathrm{~m}$ to $2.7 \mathrm{~m}$ & 0.03 & 0.97 & $18.1^{*}$ & 39.3 & 38.7 \\
\hline 5 & GW-823 & $2.7 \mathrm{~m}$ to $3.4 \mathrm{~m}$ & 0.05 & 0.95 & $18.1^{*}$ & 31.7 & 31.0 \\
\hline 6 & GW-823 & $3.4 \mathrm{~m}$ to $4.0 \mathrm{~m}$ & 0.30 & 0.70 & 18.1 & $31.7^{*}$ & 27.6 \\
\hline 7 & GW-823 & $4.0 \mathrm{~m}$ to $4.6 \mathrm{~m}$ & 0.25 & 0.75 & 15.1 & $31.7^{*}$ & 27.6 \\
\hline 8 & GW-823 & $5.6 \mathrm{~m}$ to $6.1 \mathrm{~m}$ & 0.37 & 0.63 & 17.3 & $31.7^{*}$ & 26.4 \\
\hline 12 & GW-822 & $5.8 \mathrm{~m}$ to $6.4 \mathrm{~m}$ & 0.37 & 0.63 & 16.7 & $31.7^{*}$ & 26.2 \\
\hline 15 & GW-822 & $7.0 \mathrm{~m}$ to $7.3 \mathrm{~m}$ & 0.27 & 0.73 & 13.5 & $31.7^{*}$ & 26.8 \\
\hline
\end{tabular}




\section{APPENDIX VI: Nolichucky Shale Petrophysical Data}

Summary of petrophysical data for Nolichucky Shale specimens (bedrock) from Bear Creek Valley on the ORR. Data are from Dorsch et al. (1996) who also provide additional detail. Abbreviations: $\delta_{\mathrm{He}}=$ specimen grain-density, $\delta_{\mathrm{Hg}}=$ specimen bulk-density, $\mathrm{d}_{\mathrm{Hg}}=$ geometric mean of the entire pore-throat-size distribution for the analyzed specimen, $\phi \mathrm{He}=$ effective porosity based on helium porosimetry, $\phi_{\mathrm{Hg}}=$ effective porosity based on mercury porosimetry, and $\phi_{I M S}=$ effective porosity based on the immersion-saturation method. Drill depths are given in meters below ground surface. All data are from specimens obtained from corehole GW-134. 


\begin{tabular}{|c|c|c|c|c|c|c|c|}
\hline Sampling Interval & Drill Depth [m] & $\delta_{\mathrm{He}}\left[\mathrm{g} \cdot \mathrm{cm}^{-3}\right]$ & $\delta_{\mathrm{Hg}}\left[\mathrm{g} \cdot \mathrm{cm}^{-3}\right]$ & $\mathrm{d}_{\mathrm{Hg}}[\mathrm{nm}]$ & $\phi \mathrm{He}[\%]$ & $\phi_{\mathrm{Hg}}[\%]$ & $\phi$ IMS [\%] \\
\hline A16 & 44.45 & 2.73 & 2.69 & 31.9 & 9.9 & 2.7 & $9.46^{*}$ \\
\hline A17 & 58.27 & 2.78 & 2.70 & 51.2 & 12.2 & 3.4 & $11.52^{*}$ \\
\hline A18 & 80.29 & 2.79 & 2.71 & 25.4 & 3.2 & 3.8 & $12.04^{*}$ \\
\hline A19 & 99.80 & 2.79 & 2.69 & 42.7 & 2.9 & 4.3 & 13.29 \\
\hline A20 & 109.53 & 2.76 & 2.77 & 56.6 & 4.9 & 4.3 & 15.87 \\
\hline A21 & 151.59 & 2.79 & 2.70 & 51.9 & 3.9 & 4.0 & 9.16 \\
\hline A22 & 158.27 & 2.70 & 2.68 & 58.2 & 4.7 & 5.1 & 11.60 \\
\hline A23 & 171.86 & 2.79 & 2.67 & 38.0 & 14.7 & 4.2 & 11.95 \\
\hline A24 & 181.14 & 2.77 & 2.69 & 23.1 & 4.1 & 3.7 & 11.74 \\
\hline A25 & 201.19 & 2.80 & 2.67 & 49.8 & 10.4 & 3.2 & 10.57 \\
\hline & & & & \multicolumn{4}{|c|}{$\begin{array}{l}\text { * average effective porosity of reliable IMS } \\
\text { specimens }\end{array}$} \\
\hline
\end{tabular}



Internal Distribution

1. L. D. Bates, 1001, MS-7169

2. F. P. Baxter, 3504, MS-6317

3. D. M. Borders, 1509 , MS- 6400

4. H. L. Boston, $4500-\mathrm{N}, \mathrm{MS}-6200$

5. H. M. Braunstein, 130MIT, MS-6282

6. A. J. Caldanaro, 1509 , MS- 6400

7. R. B. Clapp, 1509 , MS -6400

8. K. W. Cook, 1330, MS-7298

9. T. L. Cothron, 1001, MS-7155

19. J. H. Cushman, 1059, MS-6422

11. N. H. Cutshall, C207, MS-7172

12. M. F. P. DeLozier, 1037, MS-7355

13. A. F. Dieffendorf, 1509, MS-6400

14. W. E. Doll, 1509, MS-6400

15-21. J. Dorsch, 1509, MS-6400

22. R. B. Dreier, 1509 , MS-6400

23. T. O. Early, 1509, MS-6400

24. J. M. Forstrom, 0303-8, MS-7314

25. D. E. Fowler, 1505, MS-6035

26. C. W. Francis, 3504, MS-6317

27. D. W. Frazier, 4500-N, MS-6198

28. B. J. Frederick, 4500-N, MS-6204

29. S. B. Garland, II, 7078-B, MS-6402

30. C. W. Gehrs, 1505,6036

31. P. L. Goddard, 1330, MS-7298

32. J.-P. Gwo, 4500-N, MS-6203

33. C. S. Haase, 1330 , MS- 7298

34. R. D. Hatcher, Jr., 1509, MS-6400

35. D. S. Hicks, 1509 , MS- 6400

36. S. G. Hildebrand, 1505, MS-6037

37. J. Hodgins, 9983-58, MS-8248
38. Lucius Holder, Jr., 3001, MS-6029

39. D. D. Huff, 1509 , MS -6400

40. G. K. Jacobs, 1505, MS-6036

41. W. K. Jago, 9207, MS- 8225

42. P. M. Jardine, 1505 , MS-6038

43. S. B. Jones, 9207 , MS- 8225

44. P. Kanciruk, 0907, MS-6490

45. R. H. Ketelle, 4500 N, MS-6185

46. B. L. Kimmel, $4500-S$, MS-6125

47. A. J. Kuhaida, 7078-B, MS-6402

48. R. R. Lee, $4500-N$, MS-6185

49. S. Y. Lee, 1505 , MS-6038

50. P. J. Lemiszki, 1509, MS-6400

51. R. S. Loffman, 4500-S, MS-6102

52. R. J. Luxmoore, 1505, MS-6038

53. J. F. McCarthy, 1505, MS-6036

54. L. W. McMahon, 9116 , MS-8098

55. G. R. Moline, 1509, MS-6400

56. C. M. Morrissey, 1505, MS-6035

57. P. J. Mulholland, 1505, MS-6036

58. J. B. Murphy, 4500-N, MS-6198

59. C. E. Nix, 6026-C, MS-6395

60. M. J. Norris, $9983-A H$, MS-8247

61. J. E. Nyquist, 1509, MS-6400

62. F. S. Patton, Jr., 1001-B, MS-7169

63. D. Pridmore, 6556F, MS-6348

64. T. Purucker, 105MIT, MS-6452

65. D. E. Reichle, 4500-N, MS-6253

66. C. T. Rightmire, 1509 , MS-6400

67. T. H. Row, 4500-N, MS-6254

68. W. E. Sanford, 1509, MS-6400 
69. F. E. Sharples, 1505, MS-6036

70. L. G. Shipe, 0303-8, MS-7314

71. D. S. Shriner, 1505, MS-6038

72. R. L. Siegrist, 1505, MS-6038

73. E. D. Smith, 1505, MS-6038

74. S. H. Stow, 1505, MS-6035

75. M. F. Tardiff, 4500-N, MS-6198

76. L. E. Toran, 1509, MS-6400

77. J. R. Trabalka, 3047, MS-6020

78. J. C. Wang, 4500-N, MS-6185

79. D. R. Watkins, 3504, MS-6317
80-84. D. B. Watson, 1509, MS-6400

85. O. R. West, 1505, MS-6036

86. R. K. White, 1330, MS-7298

87. S. L. Winters, 1509 , MS-6400

88. T. F. Zondlo, 1509, MS -6400

89-93. ESD Library

94. Central Research Library

95. ORNL-Y-12 Technical Library

96-97. Laboratory Records Department

98. Laboratory Records, ORNL-RC

99. ORNL Patent Office

\section{External Distribution}

100. J. T. Ammons, Dept. of Plant and Soil Sci., University of Tennessee, TN 37901-1071

101. Jerry Archer, Geraghty \& Miller Inc., 97 Midway Lane, Oak Ridge, TN 37830

102. Richard Arnseth, SAIC, 301 Laboratory Rd., Oak Ridge, TN 37830

103. Ernest Beauchamp, C-260 Jackson Plaza, MS-7614, R13, Oak Ridge, TN 37830

104. Robert Benfield, TDEC/DOE Oversight, 761 Emory Valley Rd., Oak Ridge, TN 37830

105. G. W. Bodenstein, USDOE-OR Federal Bldg., Oak Ridge, TN 37830

106. Paul Craig, Environmental Consulting Engineers, P.O. Box 22668, Knoxville, TN 37933

107. S. N. Davis, 6540 Box Canyon Drive, Tucson, AZ 85745

108. Director, Center for Management, Utilization, and Protection of Water Resources, Tennessee Technological University, P.O. Box 5082, Cookeville, TN 38505

109. S. G. Driese, Department of Geological Sciences, University of Tennessee, Knoxville, TN 37996

110. B. E. Dugan, Department of Civil and Mineral Engineering, University of Minnesota, Minneapolis, MN 55455

111. J. F. Franklin, College of Forest Resources, Anderson Hall AR-10, University of Washington, Seattle, WA 98185

112. P. M. Goldstrand, Department of Geological Sciences, MS-172, University of Nevada, Reno, NV 89557 
113. Jim Harless, TDEC/DOE Oversight, 761 Emory Valley Rd., Oak Ridge, TN 37830

114. R. C. Harriss, Institute for the Study of Earth, Oceans, and Space, University of New Hampshire, Durham, NH 03824

115. P. Hofmann, Department of Energy, 3 Main St., Oak Ridge, TN 37830

116. G. M. Hornberger, Dept. of Environmental Sciences, University of Virginia, Charlottesville, VA 22903

117. G. Y. Jordy, Office of Program Analysis, Office of Energy Research, ER-30, G-226, USDOE, Washington, D.C. 20545

118-119. H. E. Julian, TVA Engineering Laboratory, PO Drawer E, Norris,TN 37828

120-124. T. J. Katsube, Geological Survey of Canada, Mineral Resources Division, 601 Booth Street, Ottawa, Ontario, CANADA K1A 0E8

125. D. C. Kopaska-Merkel, Geological Survey of Alabama, 420 Hackberry Lane, Tuscaloosa, AL 35486

126. O. C. Kopp, Department of Geological Sciences, University of Tennessee, Knoxville, TN 37996

127 P. E. Lamoreaux \& Assoc. Inc., P.O. Box 2310, Tuscaloosa, AL 35403

128. D. A. Lietzke, Lietzke Soil Services, Route 3, Box 607, Rutledge, TN 37861

129. Changsheng Lu, Jacobs ER Team, 125 Broadway Ave. Oak Ridge, TN 37830

130. L. D. McKay, Department of Geological Sciences, University of Tennessee, Knoxville, TN 37996

131. W. M. McMaster, 1400 West Racoon Valley Rd.

132. Manager, CH2M Hill, 599 Oak Ridge Turnpike, Oak Ridge, TN 37830

133. Manager, HSW Environmental Consultants, 687 Emory Valley Rd., Oak Ridge, TN 37830

134. Manager, Radian/Lee Wan Assoc., 120 South Jefferson Circle, Oak Ridge, TN 37830

135. Manager, Systematic Management Services, 673 Emory Valley Rd., Oak Ridge, TN 37830

136. G. K. Moore, Route 4, Box 927, Waynesboro, TN 38485

137. Ronit Nativ, Dept. of Soil and Water Sci., Faculty of Agriculture, Hebrew University of Jerusalem, P.O. Box 12, Rehovot 76100, ISRAEL

138. M. J. Neton, Geologic \& Environmental Services, 701 Cherokee Blvd., Suite G, Chattanooga, TN 37405

139. K. S. Novakowski, National Water Research Institute, 867 Lakeshore Rd., Burlington, Ontario L7R 4A6, CANADA

140. Chudi Nwangwa, TDEC/DOE Oversight, 761 Emory Valley Rd., Oak Ridge, TN 37830

141. R. H. Olsen, Microbiology \& Immunology Dept., University of Michigan, Medical Sciences II, \#5605, 1301 East Catherine St., Ann Arbor, MI 48109-0620

142. A. Patrinos, Environmental Sciences Division, Office of Health \& Environmental Research, ER-74, USDOE, Washington, D.C. 20585 
143. R. Pawlowicz, Bechtel, 151 Lafayette Dr. Oak Ridge, TN 37830

144. W. K. Puff, Dames and Moore, 575 Oak Ridge Turnpike, Oak Ridge, TN 37830

145. F. Quinones, Chief, Tennessee District, WRD, U.S. Geological Survey, 810 Broadway, Suite 500, Nashville, TN 37203

146. G. D. Reed, Dept. of Civil Engineering, University of Tennessee, 62 Perkins Hall, Knoxville, TN 37996-2010

147. N. Scromeda, Geological Survey of Canada, Mineral Resources Division, 601 Booth Street, Ottawa, Ontario, CANADA K1A 0E8

148. D. Shults, Tennessee Dept. of Environment and Conservation, Div. of Radiological Health, TERRA Bldg., 150 Ninth Ave. North, Nashville, TN 37243-1532

149. W. C. Sidle, Environmental Protection Division, USDOE-OR, P.O. Box 2001, Oak Ridge, TN 37831-8739

150. J. Smoot, Dept. of Civil Engineering, University of Tennessee, 62 Perkins Hall, Knoxville, TN 37996-2010

151. D. K. Solomon, 2381 Beacon Drive, Salt Lake City, Utah 84108

152. D. A. Stephenson, South Pass Resources, Inc., 8669 East San Alberto Drive, Suite 101, Scottsdale, AZ 85258

153. B. A. Tschantz, Dept. of Civil Engineering, University of Tennessee, 62 Perkins Hall, Knoxville, TN 37996-2010

154. G. van der Kamp, Environment Canada, 11 Innovation Blvd., Saskatoon, Saskatchewan S7N 3H5, CANADA

155. W. White, 542 Glenn Road, State College, PA 16803

156. F. J. Wobber, Environmental Sciences Division, Office of Health \& Environmental Research, Office of Energy Research, ER-74, USDOE, Washington, D.C. 20585

157. J. Young, Camp Dresser \& McGee, Suite 500, 800 Oak Ridge Turnpike, Oak Ridge, TN 37830

158-159. S. C. Young, Environmental Consulting Engineers, P. O. Box 22668, Knoxville, TN 37933

160. Office of Assistant Manager for Energy Research \& Development, USDOE-OR, P.O. Box 2001, Oak Ridge, TN 37831-8600

161-163. Office of Scientific \& Technical Information, P.O. Box 62, Oak Ridge, TN 37831 